\title{
Genealogía diacrónica del conflicto humano-jaguar
}

\author{
Angel Daen Morales Garcia y Jonatan Job Morales Garcia \\ Investigadores de Biofutura A.C., México
}

Cita recomendada. MORALES GARCIA, A.D, MORALES GARCIA, J.J., Genealogía diacrónica del conflicto humano-jaguar, dA. Derecho Animal (Forum of Animal Law Studies) 12/1 (2021). - DOI https://doi.org/10.5565/rev/da.557

\section{Resumen}

La presente obra no busca la aclamación de un público alienado de lo que quiere conocer. Este breve análisis es un elogio a la cientificidad histórico social que devela los fundamentos ocultos de la dominación humanojaguar. El objetivo es aportar elementos críticos para comprender la aniquilación sistematizada y los procesos de cosificación de este felino en el mundo social. Optamos por un análisis que d(enuncia) este encubrimiento del binomio jaguar-sociedades oprimidas el cual, ejerce un efecto totalitario cerrado. Al visibilizar la construcción histórica sobre la que han cosificado y reducido a este felino quedan expuestos los intereses de los opresores.

Palabras clave: Conservación; conflicto humano-jaguar; Mesoamérica; historia; genealogía

Abstract - A diachronic genealogy of the human-jaguar conflict

This piece does not seek the acclaim of a public alienated from what it wants to know. This brief analysis is in praise of the historical social science that reveals the hidden foundations of human-jaguar domination. The aim is to provide critical elements for understanding the systematised annihilation of and objectification processes towards this feline in the social world. We chose an analysis that (d)enunciates this concealment of the jaguar-oppressed societies binomial that has a close-minded, totalitarian effect. By making the historical construction upon which this feline has been objectified and reduced visible, the interests of the oppressors become exposed.

Key words: Conservation; human-jaguar conflict; Mesoamerica; history; genealogy. 


\section{Introducción}

La visión histórica de la aniquilación del jaguar bajo el dominio del humano, devela la represión sistematizada que pretende ocultar y olvidar el ser y la esencia del felino más grande de América, adecuando una relación de dominación que va a destruir el arraigo sociocultural de este felino con las sociedades que han sido relegadas a la periferia, y así, mantener la legitimidad y legalidad de ciertas instituciones y organismos estructurales, infraestructurales y superestructurales para continuar con su dominación hegemónica generalizada, misma que se extiende hasta nuestros tiempos.

Las relaciones de dominación que el humano ejerce sobre el jaguar en el transcurso del tiempo, tienen una base económica y simbólico social que definen el campo de la dominación. La estructura social dirigirá en cada momento histórico las características de los agentes, los sistemas de intereses e instituciones antagónicas en enfrentamiento, germinándose problemas sociales de la dominación del jaguar a lo largo de la historia del humano. Los dominantes apuntan a conservar la posición ocupada y por lo tanto, a perpetuar el statu quo, manteniendo y haciendo mantener los principios que fundan la dominación ${ }^{1}$. Esta dominación ha reducido las poblaciones del felino a niveles alarmantes, encaminándolo a su ocaso en el siglo XXI. Esta opresión tiene diversos momentos históricos que han marcado hitos que develan la sistematización y hegemonía, que incluso arroparán las estrategias para evitar la extinción de este felino, las cuales buscan realmente perpetuar la dominación del jaguar. Conocer los hitos sociales de dominación, permitirá realizar acciones adecuadas para develar la dominación, romper el statu quo y hacer época para liberar al jaguar.

\section{Genealogía diacrónica del conflicto humano-jaguar}

Desde una perspectiva diacrónica la relación humano-jaguar como fenómeno socioambiental ha generado una relación multifacética que tiene una especial importancia entre los pueblos y comunidades humanas donde interactúan ambas especies. Esta relación milenaria ha conjugado diversos momentos históricos, evidenciando elementos relevantes a lo largo del tiempo. En la gama amplia de interacciones ${ }^{2}$, tanto positivas como negativas que ha instaurado el humano hacia el jaguar ${ }^{3}$, la relación interespecífica dominante es la competencia ${ }^{4}$ asimétrica preponderante hacia humano. A manera de ejemplificar esta asimetría se ha observado que en modelos que estiman el consumo de energía, la ausencia de presas limita la reproducción en hembras de jaguar ${ }^{5}$ y que, cuando se elimina la cacería completamente en zonas sujetas a esta presión por largo tiempo, las poblaciones de jaguar y de sus presas se recuperan ${ }^{6}$, cuando el jaguar repercute en las poblaciones silvestres de sus presas no se afecta a las poblaciones humanas, contrario sensu las actividades antrópicas repercuten directamente en las poblaciones de esta especie, incluso en su reproducción.

La relación de competencia humano-jaguar es un choque entre dos especies dominantes y topes ${ }^{7}$, dando como resultado una interacción negativa hacia el jaguar. La disminución de la población de jaguares está enraizada con esta interacción y es probablemente la amenaza más importante para la conservación de esta especie $^{8}$. Para delimitar los acontecimientos históricos y entender el conflicto humano-jaguar, es importante situarse puntual y significativamente en un espacio-temporal relevante y trascendental que conforma un hito en el conflicto; estos hitos se desarrollaron desde la raíz primigenia prehistórica hasta el introito de la dominación del jaguar en el siglo XXI.

La genealogía de la dominación devela la procedencia irracional de grupos dominantes que realizan diversos procesos sociales para racionalizar la aniquilación, a través de la imposición de su modo de interpretar el mundo, representando el impulso dominante del conocimiento de la aniquilación que se sustentan en la axiología y la ontología de la dominación. Todas las cosas que viven largamente se embellecen paulatinamente

\footnotetext{
${ }^{1}$ BOURDIEU, P. El sentido social del gusto. Elementos para una sociología de la cultura. (México 2017) 153-230.

2 BEGON, M., HARPER, J., TOWNSEND, C. Ecología: Individuos, poblaciones y comunidades (Barcelona 1999).

${ }^{3}$ MORALES, A. y MORALES, J. Justicia y vida silvestre: dos estudios de caso sobre ilícitos ambientales del orden federal asociados al jaguar en México en Derecho Animal. Forum of Animal Law Studies. Vol. 9 (2018) [Última consulta: 5 de noviembre 2020] https://doi.org/10.5565/rev/da.335.

${ }^{4}$ Los humanos en entornos rurales donde se distribuye el jaguar compiten contra estos felinos por las presas,

JORGENSON, J. y REDFORD, K. Humans and big cats as predators in the neotropics en Mammals as Predators. (Oxford, 1993$) 367-$ 390. En Mammals as Predators. (Oxford, 1993).

${ }^{5}$ FOSTER, R. The Ecology of Jaguars (Panthera onca) in a Human-Influenced Landscape, (Southampton 2009).

${ }^{6}$ GONZÁLEZ-MAYA, J., BALAGUERA, S., ZÁRRATE, D. y TRUJILLO, F. Jaguarand Prey Monitoring in South American Llanos, Vichada-Colombia, Jaguar News, 19 (2008). Recuperado de https://silo.tips/download/jose-f-gonzalez-maya-msc [Última consulta: 23 noviembre 2020].

${ }^{7}$ Véase KRUUK, H. Hunter and hunted: Relationships between carnivores and people (Cambridge, 2002).

${ }^{8}$ FIGUEROA, O., FOSTER, R., WULTSCH, C., MESA-CRUZ, B., KELLY, M., HARMSEN, B., SABIDO, W., MATOLA S. y. JACOBSON, S. Estado de Conservación del Jaguar en Belice en El jaguar en el siglo XXI. La perspectiva continental. (México 2016).
} 
de razón hasta tal punto que su descendencia de la sinrazón se hace inverosímil ${ }^{9}$. La genealogía conflictual analiza el origen del pensamiento y la fuente de la opresión hacia el jaguar que en un giro dialéctico lo conceptualiza como objeto en referencia al valor histórico que lo ha sometido a la dominación, (i)racionalizandose en un objeto-cosa que se perpetua hasta la actualidad.

El abordaje genealógico del conflicto humano-jaguar es una desmitificación histórica de la dominación desde su raíz interpretativa, mostrando el origen y el desarrollo histórico de esta dominación para delimitar el devenir opresor y transformarlo, poniendo de manifiesto la contradictoriedad de la razón en la aniquilación. Esta aproximación histórica devela la ilusión que encubre la dominación bajo cimientos económicos y simbólico-culturales, misma que desde distintos momentos históricos, ha tratado de racionalizar la aniquilación del jaguar. La historia de esta dominación y aniquilación se interrelaciona con el presente y condiciona el futuro. Develarla propicia los cimientos para realizar una transformación de la dominación a la liberación; esta aproximación histórica devela una red compleja de interacciones a fin de desenmascarar el dominio como primer momento para una transformación dialéctica que libere a este felino.

\subsection{Conflicto primigenio humano-jaguar en la prehistoria}

Los ancestros del jaguar llegaron del Viejo Mundo a Norteamérica a principios del Pleistoceno, cada uno de los cuatro géneros de felinos -Smilodon, Puma, Panthera y Felis- se han reconocido en Norteamérica antes de su aparición en Suramérica ${ }^{10}$. Los registros más antiguos de la presencia de Panthera onca en el continente americano están fechados entre 820000 y 850000 años $\mathrm{AP}^{11}$, por lo que esta especie antecedió la llegada del Homo sapiens a este continente; el advenimiento de los primeros humanos a América de acuerdo a estudios históricos ${ }^{12}$ y de la evidencia genética es de aproximadamente 30000 años AP. Las evidencias arqueológicas posicionan las grandes migraciones que poblaron esta porción de tierra hace 16500 años $\mathrm{AP}^{13}$. Actualmente el registro más antiguo de restos de Homo sapiens en América data de aproximadamente 13600 AP años ${ }^{14}$. Comparando los límites extremos temporales de estas dos especies, el humano apenas lleva en América aproximadamente 3.5 centésimas porcentuales del tiempo total que el jaguar ha habitado en el continente. En este breve lapso temporal del Homo sapiens en América las poblaciones de jaguar van a ser diezmadas hasta un punto grave. Si bien este felino estuvo ampliamente distribuido durante el Pleistoceno en América, hacia el final de esta época, la distribución del jaguar se fue reduciendo paulatinamente por la presión humana asociada a su caza y destrucción de su hábitat ${ }^{15}$, derivado de la competencia en la que se encontraban estas dos especies, factores que en la actualidad se manifiestan mayormente en las sociedades rurales donde comparten nicho ecológico humanos y jaguares.

El andar del Homo sapiens dentro del continente americano en tiempos prehistóricos presenta un hito semiótico en la relación humano-jaguar que se representa en una manifestación artística pictórica de arte rupestre; en la cueva de los Machines del Corredor de cuevas prehistóricas de Yagul y Mitla, en el estado de Oaxaca, México ${ }^{16}$. Los vestigios de la ocupación de este sitio datan de hace 10000 años $\mathrm{AP}^{17}$, en él se encuentran diversas representaciones artísticas prehistóricas donde uno de los múltiples elementos pictóricos se asocia a una figura emparentada por su estructura zoomórfica al jaguar, en esta representación simbólica prehistórica de las postrimerías del Paleolítico aparece el elemento primigenio semiótico del humano en referencia a este felino a nivel continental que persiste en la actualidad. Esta manifestación simbólica es el elemento germinal con lo que iniciará la relación humano-jaguar desde dimensiones socioculturales.

\section{2 Época precolombina; el esplendor simbólico del jaguar}

En la época prehispánica las sociedades asentadas principalmente en el actual territorio mexicano ${ }^{18}$,

\footnotetext{
${ }^{9}$ NIETZSCHE, F. Aurora. Reflexiones sobre los prejuicios morales. (México 2010) 19.

${ }^{10}$ WEBB, S. Late Cenozoic Mammal Dispersals Between the Americas, en The Great American Biotic Interchange (Nueva York 1985) 357-386.

${ }^{11}$ KURTÉN, B. The Pleistocene Jaguar in North America. Bulletin of the Florida State Museum, Biological Series, 9 (1965) $215-273$.

${ }^{12}$ LEÓN-PORTILLA, M. Visión de los vencidos. Relaciones indígenas de la conquista (México 1999) 191.

${ }^{13}$ GOEBEL, T., WATERS, M. R. y O'ROURKE, D. H. The Late Pleistocene Dispersal of Modern Humans in the Americas. Science 319 (2008) Recuperado de http:// doi: 10.1126/science.1153569.

${ }^{14}$ DEL RÍO, O. Eva de Naharon. Arqueología Mexicana,157, (México 2017) 70-77.

15 ARROYO-CABRALES, J. Registro Fósil del Jaguar. En El jaguar en el nuevo milenio (México 2002) 343- 354.

${ }^{16}$ Esta zona ha sido declarada Patrimonio Mundial por la Organización de las Naciones Unidas para la Educación, la Ciencia y la Cultura (UNESCO) en la categoría de paisaje cultural en 2010 Decisión : 34 COM 8B.42. https://whc.unesco.org/es/list/1352.

17 SMITH, B. The Initial Domestication of Cucurbita pepo in the Americas 10,000 Years Ago. Science, Vol. 276, (Estados Unidos 1997) Issue 5314, 932-934 DOI: 10.1126/science.276.5314.932 https://science.sciencemag.org/content/276/5314/932 [Última consulta: 12 de noviembre 2020].

${ }^{18}$ México fue centro de una de las seis columnas de la historia universal que tiene como base social civilizatoria el florecimiento de

26 Derecho Animal. Forum of Animal Law Studies, vol. 12/1
} 
eran un gran mosaico de culturas, si bien cada una tenía sus propias características, mantenían similitudes en su cosmovisión, configurando una base cultural común que asentó a la pluriculturalidad. Esta base es denominada el núcleo duro de la tradición mesoamericana ${ }^{19}$, donde el jaguar junto con otros elementos tendrá un papel central en esta región sociocultural.

Las sociedades prehispánicas mesoamericanas mantenían una relación multifacética con el jaguar -estas sociedades tenían como cimiento a la cultura madre olmeca a quienes se les consideró el pueblo del jaguar ${ }^{20}$, por designar a este felino como un animal esencial ${ }^{21}$ : desde una dimensión simbólica y sociocultural, la época prehispánica será el esplendor cultural para la relación humano-jaguar. Este felino desde dimensiones de hierofanía y cratofanía se asociará principalmente a los siguientes elementos: poder, magia, fuerza, valentía, guerra, religión, divinidad, vida, muerte, inframundo y a la soberanía, enfocándose en gobierno, política, realeza y autoridad. Estos elementos se fusionaron con el felino y tuvieron una nueva construcción asociativa en relaciones socioculturales en lo cotidiano y lo divino, primordialmente: guerrero-jaguar, practicante mágico religioso-jaguar, sacerdote-jaguar y gobernante-jaguar. Como vemos, este mamífero representó una amplia gama de simbolismos que abarcaban sustancialmente la relación con el poder ${ }^{22}$, esta afirmación tiene un origen biológico: el jaguar al igual que el humano es parte del gremio trófico que está en la cumbre ${ }^{23}$, y es uno de los pocos animales que, de acuerdo a la tradición nahua, podía cazar a los humanos, por eso algunas comunidades lo nombraban "tecuani" 24 que significa "el comedor de hombres". Tal calificativo, frecuentemente sustituía su nombre común: "ocelotl", ya que era una creencia que la enunciación de su verdadero nombre podía provocar su inmediata aparición; este tabú lingüístico nos refleja el terror que infundía el jaguar ${ }^{25}$.

La importancia de la relación sociocultural humano-jaguar en las sociedades prehispánicas, la podemos inferir desde una dimensión semiótica deductiva, la cual se manifestó en la red intersubjetiva de las colectividades interactuantes semánticas y lingüísticas, cuyos actos mentales se refirieron a la totalidad unitaria que concibieron los miembros de una entidad social ${ }^{26}$. Estas sociedades posibilitaron la transición de una estructura a otra en el devenir-signo del símbolo ${ }^{27}$ asociado al jaguar.

Tomando como referencia la lengua náhuatl, considerado el idioma vernáculo más hablado en México $^{28}$, y por ser la lengua en la que se conserva la más copiosa literatura mesoamericana, (incluyendo la de tradición prehispánica, la que se ha producido durante el periodo novohispano y en el México independiente hasta su renacer en los tiempos actuales) el náhuatl era considerado una lengua franca que se extendió en un amplio espacio de honda raíz cultural conocido hoy como Mesoamérica ${ }^{29}$. Bajo estas premisas realizaremos una aproximación semántica a la conceptuación del jaguar en la cosmovisión mesoamericana a través del conjunto lingüístico nahua.

Las palabras que ofrecen algo de común se asocian en la memoria y así se forman grupos en el seno de los cuales reinan relaciones muy diversas. Los grupos formados por asociación mental no se limitan a relacionar los dominios que presentan algo de común, se capta también la naturaleza de las relaciones que los atan en cada caso y crea con ello series asociativas; de una palabra cualquiera puede siempre evocar todo lo que sea susceptible de estarle asociado de un modo o de otro ${ }^{30}$. Toda palabra está ligada a su contexto, del que extrae su sentido ${ }^{31}$ y el significado de una palabra es su uso en el lenguaje ${ }^{32}$.

Al utilizar como elemento radical la expresión lingüística "ocelotl", esta tenía una función de uso en los espacios socio culturales nahuas -compartido prácticamente con todas las culturas prehispánicas- que se manifestaban en la relación asociativa desde dimensiones semánticas por ser un elemento común y cotidiano a diversos términos, lo que generaba una conexión asociativa que unía estos términos in absentia en una serie

los Olmecas, (pueblo jaguar) esta civilización fue considerada una cultura madre y es donde emergue la fascinación por el jaguar que se dispersará en toda mesoamérica hasta ser parte elemental de esta región. Véase MORALES, A. y MORALES, J. Patrimonio cultural y biodiversidad; el caso del jaguar mexicano. Boletín Mexicano de Derecho Comparado, 153 (México 2019) 973-999. https://revistas.juridicas.unam.mx/index.php/derecho-comparado/article/view/13664.

${ }^{19}$ LÓPEZ, A. 2015. Las razones del mito. La cosmovisión mesoamericana (México 2015) 12.

${ }^{20}$ PIÑA, R. y COVARRUBIAS, L. El pueblo del jaguar (los olmecas arqueológicos) (México 1964) 42-48.

${ }^{21}$ Véase BERNAL, I. El Mundo Olmeca. (México 1968).

${ }^{22}$ VALVERDE, M.C. Los lenguajes del símbolo: el jaguar y el poder entre los mayas prehispánicos en Investigaciones de hermenéutica simbólica (México 2001) 192-247.

${ }^{23}$ MILLER B. y RABINOWITZ A.¿Por qué conservar al jaguar? en El jaguar en el nuevo milenio (México 2002).

${ }^{24}$ THOUVENOT, M. Diccionario náhuatl-español. Basado en los diccionarios de Alonso de Molina con el náhuatl normalizado y el español modernizado (México 2014).

${ }^{25}$ OLIVIER, G. Noches del rey jaguar. Artes de México,121 (México 2016).

${ }^{26}$ GÁMEZ, A. y LÓPEZ, A. Cosmovisión mesoamericana. Reflexiones, polémicas y etnografías (México 2015) 67 y ss.

${ }^{27}$ DERRIDA, J. De la Grammatologie (París 1967).

${ }^{28}$ VALLE, E. Nahuas de la Huasteca. Comisión Nacional para el Desarrollo de los Pueblos Indígenas (México 2005).

${ }^{29}$ LEÓN-PORTILLA, HERNÁNDEZ DE, A. El náhuatl y el tronco lingüístico yutonahua. Arqueología Mexicana, 109 (2011) $32-37$.

${ }^{30}$ DE SAUSSURE, F. Curso de Lingüística General (Buenos Aires 1945) 142-151.

${ }^{31}$ GUIRAUD, P. La sémantique (París 1955) 54.

${ }^{32}$ WITTGENSTEIN, L. Investigaciones filosóficas (México 1988) 61. 
mnemónica virtual, destacándose aquellos que se vinculan a los siguientes elementos: poder, magia, fuerza, valentía, guerra, religión, divinidad, vida, muerte, inframundo y a la soberanía enfocándose en gobierno, política, realeza y autoridad como ya se ha mencionado. Con la destrucción civilizatoria de las sociedades prehispánicas por el avasallamiento europeo, la riqueza lingüística de "ocelotl” disminuirá de manera gradual, al igual que la riqueza cultural y lingüística de las sociedades indígenas, sin embargo, pese al daño ocasionado por las sociedades europeas en la colonia, aun quedan remanentes lingüísticos que nos dan una aproximación al término lingüístico "ocelotl” y su relación asociativa, mismos que aún se reflejan en algunas sociedades en la actualidad.

Derivado de la importancia ingente del felino en el imaginario simbólico de las culturas mesoamericanas, existe una amplia gama semántica que incluye la palabra "ocelotl". En una aproximación lingüística se analizan algunas palabras construidas que tomaban como base esta palabra para confirmar las atribuciones con las que se asocia a este felino, así como su función de uso en el sistema de significación y comunicación:

1) "Oceloyotl": valentía, braveza, grandeza, hazaña.

2) "Ocelopetlatl": nombre que se daba al soldado valiente y osado.

3) "Ocelotia": ser gran señor, ser honrado, estimado.

4) "Cuauhtlocelotl": hombre diestro en las armas 33

5) "Ocelotonatiuh": Sol jaguar ${ }^{34}$.

"Ocelotl" era por su connotación sociocultural una palabra asociada a un gran número de sentidos, asimismo cuenta con una frecuencia grande, por lo que podemos aseverar que esta palabra al posicionarse como el centro de la constelación tiene asociaciones vinculadas por función de uso a los elementos señalados anteriormente. La palabra "ocelotl" y sus dimensiones semióticas en los campos lingüísticos despliega las múltiples intenciones de su símbolo y reflejan la profundidad simbólica unificada del jaguar en las sociedades mesoamericanas, manifestándose como un ente cultural en la cosmovisión indígena. (Figura 1).

El conjunto lingüístico de este felino se expresó en nombres propios que tenían relación asociativa del campo semántico de "ocelotl", existiendo una relación de un nombre propio cuya denotación se establece mediante la designación individual inicial del nombre y se mantiene gracias a una cadena causal que une en sus extremos al objeto o individuo denotado, con el usuario del nombre ${ }^{35}$.

En el amplio campo semántico que refiere al ámbito de lo religioso-divino, encontramos que "ocelotl" se asociaba principalmente con "Tepeyolotl" "36; corazón de monte, Tezcatlipoca ${ }^{37}$ y con Tonatiuh ${ }^{38}$. El Códice Chimalpopoca ${ }^{39}$ evidencia la relación sociocultural en un espacio mítico, religioso y divino de la cosmovisión nahua con este felino, grosso modo se puede observar, por una parte, que en los Anales de Cuauhtitlán se menciona que el segundo sol que existió era del signo "4 Ocelotl" llamado Ocelotonatiuh -sol del jaguar-. Asimismo, en la Leyenda de los Soles se menciona que la primera creación del mundo o el primer sol cosmogónico fue el sol "nahui ocellotl" (4 "ocelotl")-. Si bien el orden de lo descrito en los Anales y en la Leyenda no se corresponden con exactitud, lo que nos interesa resaltar es que ambos consideran al jaguar en la visión cosmogónica y mítica de los nahuas.

La relación semiótica humano-jaguar tendrá un profundo arraigo en las expresiones culturales de las sociedades prehispánicas del continente americano, expresándose en correlatos creacionistas con elementos simbólicos compartidos y, tal como apuntamos, se extendieron por todo el horizonte cultural mesoamericano; para la zona sur de México, en la cultura zapoteca el jaguar está asociado con el culto al dios padre "Péchetáo" o "Pitao Peeche", el dios jaguar", entre los mayas al jaguar se le denominará "balam", este vocablo aludía a lo oculto, lo extrahumano y lo sagrado, vocablo que unido con "Chilam Balam" significaba: el que es boca de lo oculto, lo que se asociaba con los sacerdotes o profetas jaguares ${ }^{41}$.

\footnotetext{
33 Véase REMI, S. Diccionario de la lengua náhuatl o mexicana, redactado según los documentos impresos y manuscritos más auténticos y precedido de una introducción (México 1977).

${ }^{34}$ Véase VELÁZQUEZ, P. (trad.) Códice Chimalpopoca, Anales de Cuautitlán y Leyenda de los Soles, México, (UNAM 1992).

${ }^{35}$ KRIPKE, S. Identity and necessity en MUNITZ M. (ed.), Identity and Individuation (New York 1971)

${ }^{36}$ OLIVIER, G. Tepeyóllotl, «Corazón de la montaña y Señor del eco»: el dios jaguar de los antiguos mexicanos, Estudios de Cultura Náhuatl, 28 (1998) 99-140.

${ }^{37}$ SAUNDERS, N. Tezcatlipoca: jaguar metaphors and the Aztec Mirror of Nature en Signifying Animals: Human Meaning in the Natural World (London 1990) 159-177.

${ }^{38}$ MORALES, A. y MORALES, J. Patrimonio cultural y biodiversidad; el caso del jaguar mexicano. Boletín Mexicano de Derecho Comparado, 153 (México 2019) 973-999. https://revistas.juridicas.unam.mx/index.php/derecho-comparado/article/view/13664.

${ }^{39}$ VELÁZQUEZ, P. (trad.) Códice Chimalpopoca, Anales de Cuautitlán y Leyenda de los Soles, México, (UNAM 1992).

${ }^{40}$ DE LA CRUZ,V. El pensamiento de los binnigula'sa': cosmovisión, religión y calendario con especial referencia a los binnizá (México 2007) 141-142.

${ }^{41}$ BARRERA, A. (trad.).El libro de los libros de Chilam Balam (México 2005) 10 y ss.

28 Derecho Animal. Forum of Animal Law Studies, vol. 12/1
} 


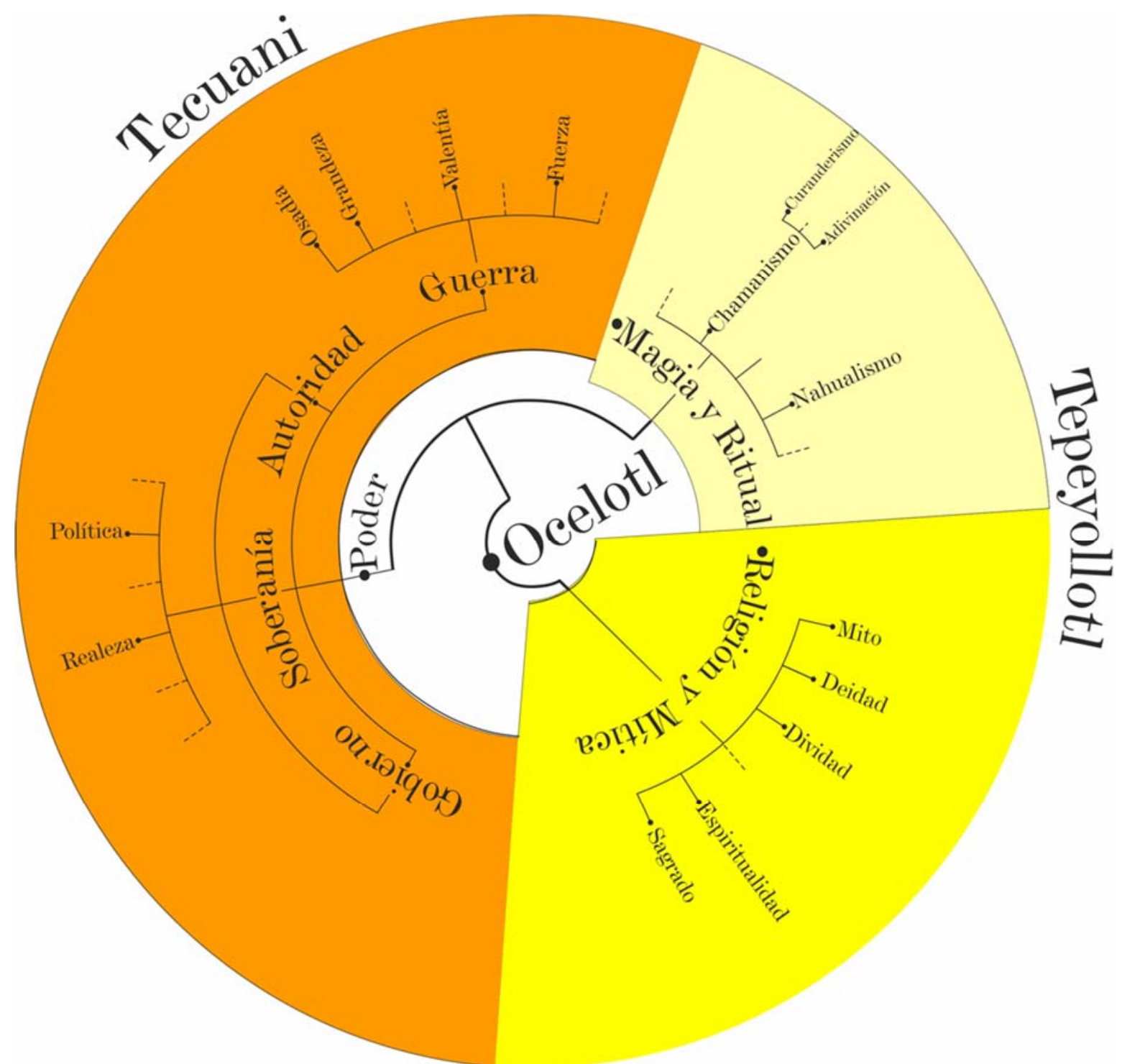

Figura 1. Aproximación al campo semántico del jaguar “Ocelotl” en la cultura nahua (Fuente: elaboración propia).

Si bien, los vocablos donde la palabra "ocelotl" está presente son registros invaluables de la omnipresencia del felino en la constitución simbólica de las culturas mesoamericanas, es necesario tener en cuenta que tanto el vocablo como su grafía no comprenden del todo las concepciones meramente indígenas. Es cierto, también forman parte del cuerpo documental del que se parte para la reconstrucción de un universo distante -temporal y cualitativamente-, pero es necesaria esta consideración. Tanto los pictogramas, ideogramas y signos fonéticos que han quedado registrados en la documentación y las profusas investigaciones que se han detenido en detallar los elementos gráficos en la composición histórica de estos pueblos, ambos son directrices para el estudio de la impronta del jaguar como elemento simbólico, pero también como un numen del panteón mesoamericano.

Aunque aún hay desacuerdo en tanto a su composición como una deidad en sí misma, investigaciones históricas ${ }^{42}$ nos dan la posibilidad de entender este entramado de redes significantes como derivados de una entidad nominal compleja en sí misma: Tezcatlipoca. Estas propuestas nos permiten constatar que la relación del jaguar en su advocación de "Tepeyollotl" y su relación con la tierra, lo húmedo y la vida, no pueden ser menos que la contraparte en la díada del principio divino. De ahí que todos sus significantes (Figura 1), por lo menos en las sociedades altamente jerarquizas y militarizadas, como lo fueron la maya, la mexica y la mixteca, aludan al jaguar en las connotaciones antedichas. En este tenor, resulta ilustrativo retomar diversas prácticas rituales de ceremonias de entronización de gobernantes ${ }^{43}$ y guerreros en Mesoamérica a quienes se les perforaba la nariz con un punzón o hueso de jaguar para colocarles una nariguera o su uso en rituales para sangrar orejas y diversos órganos. En las sociedades nahuas, los "tetecuhtin" ${ }^{44}$ de Tlaxcala, durante sus ritos

${ }^{42}$ Op. cit. OLIVIER, G. (1998) 100.

${ }^{43}$ Véase VELA, E. "Narigueras", Arqueología Mexicana, edición especial núm. 37 (México, 2010) 82-87.

${ }^{44}$ Tetecuhtin: era el jefe de un teccalli o "casa de gobierno", es decir, una unidad política gobernada por él. Véase LÓPEZ, A. La 
de ascenso al poder se les perforaba la nariz con una garra de águila y un hueso de jaguar ${ }^{45}$, lo que se hacía para significar de acuerdo a Fray Toribio de Benavente ${ }^{46}$ que habían de ser "en la guerra muy ligeros para seguir y alcanzar a sus enemigos, como águilas, y fuertes y animosos para pelear como tigres". En la cultura maya, las insignias del poder de los gobernantes "Kaweq" incluían garras de águila y jaguar, además de huesos del felino. El Título de Totonicapán, que es considerado de los acervos literarios más importantes para el conocimiento de la cultura maya ${ }^{47}$, describe el rito de "K'iqab" que menciona que los señores fueron perforados y cortados con (...) las garras de águila y jaguar ${ }^{48}$. El Título de Yax $^{49}$ menciona que además de las garras se daban al gobernante huesos de jaguar. Asimismo, el jaguar en estas sociedades era parte de rituales asociados a su tortura y sacrificio ${ }^{50}$. Entre los mixtecos, el sacrificio y los rituales de poder con punzones de jaguar era una costumbre de los soberanos, esto se puede apreciar en el Códice Nuttall, donde 8 Venado Garra de Jaguar ${ }^{51}$ se somete a los rituales. Estas prácticas culturales reflejan el acentuado peso no sólo simbólico del acto, sino también del instrumental y ritual desarrollado en él. Los elementos materiales e inmateriales del jaguar confluían en la praxis cultural mesoamericana asociada a este felino.

El arte pictórico-literario de construcción poética conformado en una gama de expresiones de raíces prehispánicas -códices, leyendas, textos sagrados entre otros elementos- de las culturas indígenas, así como los elementos culturales inmateriales, expresan la relación biocultural humano-jaguar. Este profundo simbolismo nutre a la sociedad y da sentido a un mundo que se va tejiendo por la semiótica. La importancia del jaguar se devela en las imbricaciones de los elementos inmateriales que confluyen en las expresiones artísticas que se conjugan con los elementos materiales que las soportan, por ejemplo, la construcción del material del Códice Laúd o Libro de los Destinos está hecho con piel de jaguar ${ }^{52}$.

Las connotaciones que refieren al jaguar "ocelotl" refleja la gama amplia del simbolismo de este felino en los procesos comunicativos. El símbolo y los relatos míticos que envuelven a este animal son el modo de expresar la sabiduría y la cosmovisión de las sociedades humanas donde existe una interacción con esta especie, el basto conjunto de mitos asociados al jaguar presenta un común denominador en la atribución de una misma función simbólica. La función semántica de los mitos, nos menciona Lévi-Strauss, es atestiguar que existe un isomorfismo entre dos tipos de órdenes que pueden ser, según los casos, el orden cósmico y el orden cultural; el orden cósmico o meteorológico y el orden social, o uno cualquiera de estos órdenes y el orden zoológico, que reside en un nivel medio en relación con ellos ${ }^{53}$. El ropaje simbólico que envuelve al jaguar nos remite a una comprensión de la manifestación histórica y cultural que las sociedades indígenas en América establecieron con este felino en niveles cotidianos, así como desde una visión originaria de lo sagrado, enmarcándose como un símbolo fundamental en la conciencia de los pueblos y comunidades mesoamericanas.

La simbólica del jaguar es pieza clave de la realidad humana precolombina, es un elemento sagrado que incorpora y revela algo distinto de él mismo, es una hierofanía que separa a este elemento natural saturado de sacralidad con respecto al resto que lo rodea, dejando de ser un simple elemento profano. La hierofanía del jaguar está constituida por todas las experiencias religiosas sociales y comprende, además, un cuerpo de tradiciones teóricas ${ }^{54}$. El jaguar tuvo una valorización de hierofanías y de cratofanías por integración en la epifanía de lo sacramental supremo en las principales sociedades mesoamericanas. Esta relación de hierofanía con la cratofanía se dio en dimensiones integrales y también se expresó de manera ambivalente; la cratofanía del jaguar como manifestación de fuerza y por consiguiente; temido y venerado, refleja la ambivalencia de lo

educación de los antiguos nahuas. VOL. II (México 1985) 154. Dicha unidad disponía de tierras y de personas del común que daban tributo y servicios al tecuhtli en compensación por sus oficios públicos. Este personaje también realizaba un rito para acceder a su cargo y podía ser alcanzado por principales de linaje, mercaderes, sacerdotes y guerreros. Véase CARRASCO, P. "Cultura y sociedad en el México antiguo", Historia general de México (México 2000) 153-233.

${ }^{45}$ ALATORRE, D. El rito para acceder al cargo de Ajpop entre los k'iche's de Q'umarkaj. Estudios de cultura maya. versión impresa ISSN 0185-2574, vol.54 México sep. 2019 https://doi.org/10.19130/iifl.ecm.2019.54.977

${ }^{46}$ Véase BENAVENTE, fray Toribio de (Motolinía) Memoriales o libro de las cosas de la Nueva España y de los naturales de ella, Edmundo O' Gorman (ed.) (México 1971) 339.

${ }^{47}$ MORSELLI, S. El Título de Totonicapán: consideraciones y comentarios. Estudios Mesoamericanos núm. (México 2004).

${ }^{48}$ CARMACK, R. Y MONDLOCH, J. Título de Totonicapán (México 1989) 196.

${ }^{49}$ CARMACK, R. y MONDLOCH, J. Título de Yax y otros documentos quichés de Totonicapán, Guatemala, (México 1989) 33-128.

${ }^{50}$ Véase FRANÇOIS, C. El dolor redentor. El autosacrificio prehispánico. Universidad Nacional Autónoma de México. (México 2013).

${ }^{51}$ Véase ANDERS, F., JANSEN, M. y REYES L. Crónica mixteca. El Rey 8 Venado, Garra de Jaguar, y la dinastía de Teozacualco, Zaachila. Libro explicativo del llamado códice Zouche-Nuttall (México 1992).

${ }^{52}$ SNIJDERS, L. Seeing spots: Identification of a codex cover. Mexicon, 36 (2014), 13-14 Recuperado de https://www.academia.edu/10337073/Seeing_Spots_Identification_of_a_codex_cover [Última consulta: 6 de noviembre 2020].

${ }^{53}$ LÉVI-STRAUSS, C. Mitologías. Lo crudo y lo cocido (México 1968) 310 y ss.

54 ELIADE, M. Tratado de la historia de las religiones. Tomo I (Madrid 1974) página 55 y ss. Recuperado de http://pdfhumanidades.com/sites/default/files/apuntes/200-Eliade.Mircea_Tratado-de-historia-de-las-religiones.pdf [Última consulta: 30 de noviembre 2020].

30 Derecho Animal. Forum of Animal Law Studies, vol. 12/1 
sagrado de esta especie no sólo de orden psicológico, sino en un orden axiológico y ontológico.

Por efecto de las hierofanías y las cratofanías asociadas a este felino, el jaguar tendrá una transfiguración que adicionará una gran carga de mitos ${ }^{55}$, teniendo desde espacios sacramentales un papel simbólico fundamental. De acuerdo a Mircea Eliade, la función del símbolo se mantiene invariable: transformar un objeto o un acto en algo distinto de lo que ese objeto o ese acto son en la perspectiva de la experiencia profana ${ }^{56}$. El jaguar en los procesos culturales recibe un valor en la experiencia mágico-religiosa del humano en la medida que simboliza una epifanía de lo sagrado, este símbolo pertenece a un sistema complejo y estructurado que da que pensar, ya que el símbolo, según Paul Ricoeur, da que pensar; pero lo que da es que pensar, algo que pensar, en su apreciación dual, esta sentencia indica que el símbolo da; yo no pongo el sentido, él es quien da sentido; pero lo que da es a pensar, algo a pensar ${ }^{57}$.

La dimensión semiótica asociada al jaguar en este periodo tiene un vínculo intrínseco con la pluralidad de relaciones con este felino; dentro de las relaciones que causaron afectaciones en esferas ecológicas se destacan aquellas que emergen por la utilización de partes de este felino, algunos grupos sociales prehispánicos principalmente aquellos asociados a la soberanía, órdenes superiores de gobernantes, realeza, órdenes superiores de guerreros y en prácticas mágico-religiosas van a utilizar sus partes y derivados principalmente piel, garras, huesos, piezas dentales ${ }^{58}$, sangre, grasa, carne y corazón en espacios de cotidianidad y en lo sagrado. La importancia que llegó a tener este felino fue tal que, de acuerdo a los pictogramas correspondientes a la segunda parte del Códice Mendoza ${ }^{59}$ y la Matricula de los Tributos establecen que la piel de este felino era parte del conjunto tributario y era una mercancía de gran valor en el comercio y las relaciones sociopolíticas prehispánicas de diversos grupos sometidos bajo la Triple alianza conformada por Mexico-Tenochtitlan, Tetzcoco y Tlacopan ${ }^{60}$. Fue tanta la fascinación por este animal que existen relatos de que el "tlatoani" -supremo gobernante en épocas prehispánicas de la Triple alianzaconsumía caldo de carne de jaguar con el fin de volverse valiente y obtener honores ${ }^{61}$. En la actualidad algunos miembros del pueblo indígena triqui asentado en el estado de Oaxaca consumen carne de jaguar (especie que ellos denominan león o lion; desde la conquista los españoles designaron así al jaguar y al puma por desconocimiento taxonómico ya que en el continente americano no existen leones de manera natural). Para algunas personas esta carne es apreciada ya que de acuerdo a su cosmovisión todo aquel que la come, le proporciona la fuerza del animal, asimismo es considerada curativa y preventiva de cualquier enfermedad incluso tienen la falsa creencia que la grasa de este animal ayuda a quitar dolores ${ }^{62}$. Esta práctica asimétrica devastadora refleja la relación milenaria aniquiladora del humano sobre el jaguar desde una dimensión social asociada al poder y dominio del hombre sobre la naturaleza; la visión mítica y simbólica que encarna esta especie la orilló a ser perseguida en sitios donde interactúa con los pueblos indígenas, desde tiempos prehispánicos y que subsiste hasta en la actualidad en una pluralidad de manifestaciones culturales.

La cacería de jaguar en la época prehispánica se dio principalmente por las relaciones de este felino con el poder, lo mágico-ritual y la religión desde una connotación basada prima facie en: 1) carga simbólica del jaguar en las construcciones socioculturales e interculturales y 2) relación de dominación del humano sobre la naturaleza. Pese a que esta dimensión es antiquísima, en la actualidad aún persiste la idea arcaica en algunas poblaciones -principalmente del centro-sureste de México- y artesanos que venden productos elaborados con partes de este felino, en la que según el uso de partes de jaguar brinda elementos mágicos, religiosos y de poder (Imagen 1 y 2 ).

\footnotetext{
${ }^{55}$ ELIADE, M. Tratado de historia de las religiones. Tomo II (Madrid 1974) 149. Recuperado de http://www.fraternidadrosacruzdecolombia.org/wp-content/uploads/2013/12/262_eliade-mircea-tratado-de-historia-de-dasreligiones-ii.pdf [Última consulta: 30 de noviembre 2020].

${ }^{56}$ ELIADE, M. Tratado de historia de las religiones. Tomo II (Madrid 1974) 236. Recuperado de http://www.fraternidadrosacruzdecolombia.org/wp-content/uploads/2013/12/262_eliade-mircea-tratado-de-historia-de-dasreligiones-ii.pdf [Última consulta: 30 de noviembre 2020].

${ }^{57}$ RICOEUR, P. Finitud y Culpabilidad (Madrid 2004) 481 y ss.

58 Véase LÓPEZ, L. 1993. Las ofrendas del Templo Mayor de Tenochtitlan (México 1993); RAGSDALE, C., EDGAR, H. \& MELGAR, E. Origins of the Skull Offerings of the Templo Mayor, Tenochtitlán. Current Anthropology, Volume 57 (2016).

${ }^{59}$ GALINDO, J. Códice Mendoza (México 1980) XI.

${ }^{60}$ BATTCOCK, C. La conformación de la última "Triple Alianza" en la Cuenca de México: problemas, interrogantes y propuestas. Dimensión Antropológica, 52, (2011) 7. http://www.dimensionantropologica.inah.gob.mx/wp-content/uploads/01Dimension52.pdf [Última consulta: 3 de noviembre 2020].

${ }^{61}$ Op. cit. OLIVIER, G. (1998) 126.

${ }^{62}$ MENDOZA, Z. De lo biomédico a lo popular. El proceso salud-enfermedad. Atención en San Juan Copala, Oaxaca (México, 2011) 59.
} 


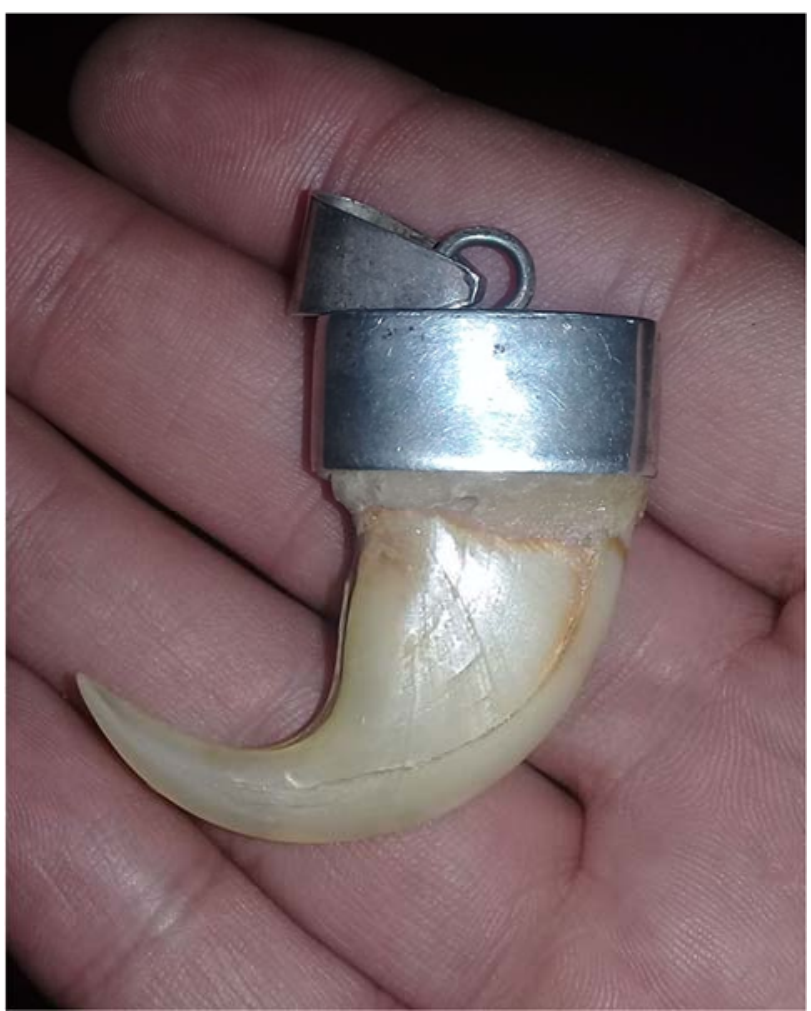

Imagen 1. Garra de jaguar confeccionada en plata como supuesto amuleto (Fuente: autor desconocido. Cortesía de Biofutura A.C.)

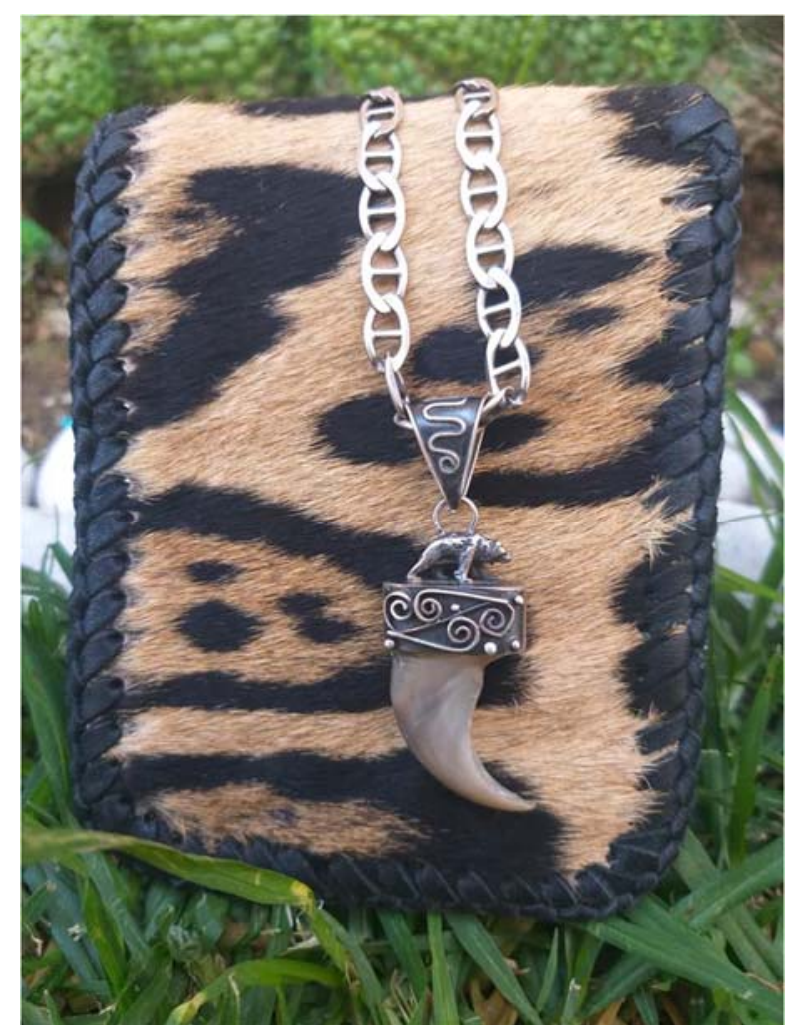

Imagen 2. Cartera confeccionada con piel de jaguar y una garra de oso (Fuente: autor desconocido. Cortesía de Biofutura A.C.)

\section{3 Época colonial; el asedio del jaguar}

Para los grupos culturales mesoamericanos la cuenta del tiempo y de sus orígenes míticos, representados en infinidad de registros pictográficos, narrativos, arquitectónicos, ornamentales y cotidianos, se encuentran en dos esferas distintas asociadas a elementos del "tloque nahuaque"63: "el aquí y el ahora y el allá y el

${ }^{63}$ Véase LEÓN-PORTILLA, M. La Filosofía Náhuatl Estudiada en sus Fuentes. Universidad Nacional Autónoma de México. (México 2019).

32 Derecho Animal. Forum of Animal Law Studies, vol. 12/1 
entonces" $" 64$ donde en ambas dimensiones, el jaguar es omnipresente. El momento de la colonización española representó un corte tajante en este cómputo, que, como tal, requirió de otros soportes para registrarlo. La transición de la cultura comunicativa indígena -eminentemente oral, pero con un muy definido sistema pictográfico- manifiesta en las tradiciones mesoamericanas hacia una cultura comunicativa en letras e idiomas latinos, sin duda alguna representa unas de las rupturas simbólicas más drásticas del universo cosmogónico mesoamericano. Al tiempo que influyó en las formas lingüísticas y comunicativas de los colonizadores. En el primero de los casos fue necesaria la aprehensión (voluntaria o bajo cohesión) de los sistemas de conocimiento y organización del universo totalmente diferentes al que hasta antes de 1521 se habían consolidado como los únicos válidos y autorizados. Después, el uso de estos conocimientos en función de los requerimientos contextuales. La occidentalización de las culturas indígenas de los siglos XVI al XVIII tiene como pilares la cristianización, la imposición del sistema colonial, la redefinición de lo imaginario y de lo real en que los pueblos indígenas fueron destinados a expresarse y a subsistir; al margen de la manifestación brutal y autoritaria del colonialismo y por la fascinación de Occidente ${ }^{65}$. Este punto es fundamental al momento de construir los cimientos sobre los cuales se asienta el asedio del jaguar.

Se estima que más de 100000 jaguares poblaban el continente cuando los españoles colonizaron estas tierras, hacia finales del siglo $\mathrm{XV}$ y principios del $\mathrm{XVI}^{66}$. Esta población era altamente viable pese a las condiciones de la época precolombina. Durante el periodo de imposición española, el imperialismo ecológico en relación asimétrica dominante por la biota europea ${ }^{67}$, conformada por el animal humano europeo, animales domésticos, plantas, y el conjunto de parásitos y microorganismos a ellos asociados, fue un elemento importante en el éxito de la conquista y ocupación del continente americano ${ }^{68}$. El fenómeno de transculturación en conjunto con la biota mixta, generó un cambio en las estructuras sociales y biológicas, principalmente en la relación con la biodiversidad y en la cosificación de los demás animales, donde algunos como el jaguar -en un giro dialéctico- pasaron de ser elementos con una gran carga simbólica de dimensiones sacramentales a ser seres problemáticos bajo una simbólica del mal a través del proceso de degradación simbólica y desacralización. Un elemento importante de este hito es el conflicto que surgiría con la ganadería -conformada con especies exóticas domésticas ajenas a la tradición prehispánica- por la depredación, propiciando un aumento significativo en la cacería de esta especie, que, antes de la llegada de los españoles, era una actividad que, hacía mucho tiempo, había dejado de ser económicamente significativa ${ }^{69}$. En la conquista las especies ganaderas provenientes de Europa, consolidaron con los siglos una importancia social, llegando a ser consideradas como expresión de riqueza y fuente de prestigio ${ }^{70}$. Las vacas, los cerdos, las aves esclavizadas para consumo humano en conjunción con el colonialismo y el cristianismo de dominación van a degradar, desplazar y a desacralizar el poder simbólico del jaguar, posicionándolo en la periferia junto a los pueblos dominados.

El desprendimiento simbólico del jaguar en la conquista española prima facie generó una ruptura y una herida en las sociedades indígenas, engendrando un sentimiento de soledad. La relación humano-jaguar en este periodo y hasta la actualidad se rigen bajo el pensamiento cristiano-colonial de la dominación, lo que genera un repudio hacia este ser, ejemplificando un simbolismo del mal y estableciéndose un conflicto que aún no se ha resuelto. La dominación europea tuvo una gran repercusión sociocultural en Mesoamérica que se replica en las sociedades modernas; esta repercusión de largo alcance es el reflejo significativo derivado del continuum semiótico en las transformaciones simbólicas al interior de la semiosfera que se halla en diversos niveles de organización de las sociedades mesoamericanas ${ }^{71}$. Los elementos simbólicos asociados al jaguar en este periodo, tuvieron una afectación de largo alcance por la dominación europea que repercutió en la semiosfera y en la complejidad semiótica que rodeaban a esta especie, incluso la afectación trasciende en dimensiones ecológicas al llevar al borde de la extinción a este felino. Si bien la historia de las religiones es en gran parte la historia de las desvalorizaciones y revalorizaciones del proceso de manifestación de lo

\footnotetext{
${ }^{64}$ LÓPEZ, A. y MILLONES, L. Dioses del Norte, Dioses del Sur. Religiones y cosmovisión en Mesoamérica y los Andes (México 2008) 68-71.

${ }^{65}$ Véase GRUZINSKI, S. La colonización de lo imaginario. Sociedades indígenas y occidentalización en el México español. Siglos XVI-XVIII (México 2013).

${ }^{66}$ CEBALlOS, G. Los felinos de América (México 2010) 34.

${ }^{67}$ CROSBY, A. El imperialismo ecológico (Barcelona 1988) 78.

${ }^{68}$ YEPES, F. Ganadería y transformación ecosistemas: un análisis ambiental de la política de apropiación territorial en Naturaleza en disputa. Ensayos sobre historia ambiental de Colombia, 1850-1990 (Bogotá 2001)

111-172.

${ }^{69}$ OLIVIER, G. Cacería, sacrificio y poder en Mesoamérica. Tras las huellas de Mixcóatl, "Serpiente de Nube" (México 2015).

${ }^{70}$ STEINFELD, H., GERBER, P., WASSENAAR, T., CASTEL, V., ROSALES, M. y DE HAAN, C. La larga sombra del ganado. Problemas ambientales y opciones. Recuperado de http://www.fao.org/3/a-a0701s.pdf [Última consulta: 23 noviembre 2020 ] 303.

${ }^{71}$ LOTMAN, I. M. La semiótica de la cultura y el concepto de texto. Recuperado de

http://cmas.siu.buap.mx/portal_pprd/work/sites/escritos/resources/LocalContent/40/1/15-20.pdf [Última consulta: 10 noviembre 2020].
} 
sagrado $^{72}$, el sincretismo cultural asociado al jaguar presenta una gama amplia de manifestaciones, por ejemplo, una variante cultural toma una valorización negativa que lo considera un ser maligno que necesita exterminarse $^{73}$. Asimismo, en el abanico del dinamismo cultural inherente a todo proceso cultural, el jaguar es convertido en otras unidades a través de la transformación simbólica ${ }^{74}$. Como última opción de manera elemental el jaguar sigue teniendo las referencias simbólicas degradándose temporalmente en las prácticas culturales principalmente en zonas rurales de México. Los aspectos culturales que se representan asociados al jaguar, si bien se diferencian y presentan variaciones, todas comparten una unidad simbólica que se conjetura en una gran matriz cultural que persiste en la actualidad en algunas zonas de México.

Para dimensionar la ruptura humano-jaguar, debemos adentrarnos en el encubrimiento de los pueblos y comunidades indígenas mesoamericanos bajo la relación asimétrica de exclusión del dominanteconquistador sobre el oprimido-conquistado que inició en octubre de 1492, cuando se toma posesión de espacios territoriales insulares de América por parte de la corona española ${ }^{75}$; dicha exclusión se justificó por una argumentación encubiertamente teológica: se trata de la superioridad reconocida o inconsciente de la cristiandad como elemento dialéctico sobre las religiones indígenas, generando un total desprecio por lo indígena principalmente los ritos, los dioses, los mitos y las creencias. El dominante conquistador implementó una política inquisitorial cuya finalidad era borrar todos los elementos indígenas simbólico-culturales con un método de tabula rasa ${ }^{76}$.

La cristiandad europea -donde se incluye la hispánica- tomó a la religión como justificación de todas sus atrocidades con respecto a los pueblos y comunidades de América, totalizando con una cultura de dominación basada en la religión cristiana. El proceso de dominación se basó en quitar la dignidad a los dominados dentro del sistema totalitario, configurándolos como los enemigos, los de la periferia, los demoniacos, los fuera del sistema: el no-ser ${ }^{77}$. Este proceso trató de justificarse bajo la conquista espiritual ${ }^{78}$ dominadora para evangelizar, hispanizar e invisibilizar al otro en el sistema totalitario opresor español que imputó la grandeza de las civilizaciones indígenas en América como producto del arte maligno de un ser sobrenatural: el demonio. Por tal razón, la destrucción de la obra diabólica fue resultado lógico del pensamiento dominador cristiano ${ }^{79}$. El cristianismo bajo la teología de la dominación ${ }^{80}$ configuró los intereses de la clase dominadora sobre las naciones pluriculturales oprimidas, imponiendo preponderantemente bajo el cristianismo la idea teológica especista sacra de la vida humana frente a otros seres que serán reducidos al dominio del humano. Esta idea teológica cristiana asoló la diversidad religiosa cultural de las sociedades indígenas que en unidad consideraba animada a toda la naturaleza, estas sociedades establecían con los animales diferentes vínculos psicológicos y emocionales, consideraban que los animales tenían una relación especial con lo divino, lo que los posicionó en un elemento privilegiado en las representaciones de las ideas fundamentales de la cultura, existiendo una intercomunicación entre humanos y animales ${ }^{81}$. La simbología zoomorfa operaba como vehículo comunicante entre los humanos y lo sagrado, además de identificar hombres-dioses y númenes específicos ${ }^{82}$, la voz predominante en los mitos mesoamericanos era la de los animales, donde el jaguar era de los elementos bioculturales con mayor representatividad en el imaginario de las sociedades prehispánicas. La presencia de los animales era de tal importancia en el apartado mítico que diversos especialistas han llegado a calificar el tiempo-espacio mítico como el tiempo en que los animales hablaban ${ }^{83}$. La palabra como revelación del otro en la dominación española fue negada, como la palabra vista y leída dentro de la totalidad de la interpretación óntica y ontológica ${ }^{84}$. Este otro es el indígena y el animal no humano, con la teología de la dominación y la imposición española bajo la totalización especista de la palabra dominante y hegemónica silenciaron a los animales, a los pueblos indígenas y con ello dieron muerte al logos

72 ELIADE, M. Tratado de historia de las religiones. Tomo I http://pdfhumanidades.com/sites/default/files/apuntes/200Eliade.Mircea_Tratado-de-historia-de-las-religiones.pdf [Última consulta: 23 de noviembre 2020].

${ }^{73}$ HORCASITAS, F. La danza de los tecuanes. Estudios de Cultura Náhuatl, 14 (México 1980) 246, 248, 249,251 y 254.

${ }^{74}$ RAMÍREZ, J. 2012. El jaguar transformado. Una hipótesis poliédrica a propósito de la danza "El caballito blanco". Estudios de cultura maya, 40 (2012) 191-225.

${ }^{75}$ COLÓN, C. Los Cuatro Viajes del Almirante y su Testamento (España 1980) 76.

76 DUSSEL, E. 1492 : el encubrimiento del otro : hacia el origen del mito de la modernidad (1994) Recuperado de http://biblioteca.clacso.edu.ar/clacso/otros/20111218114130/1942.pdf [Última conslta: 20 de octubre 2020].

77 DUSSEL, E. 1492 : el encubrimiento del otro : hacia el origen del mito de la modernidad (1994) Recuperado de http://biblioteca.clacso.edu.ar/clacso/otros/20111218114130/1942.pdf [Última conslta: 20 de octubre 2020]

${ }^{78}$ RICARD, R. The Spiritual Conquest of Mexico. An Essay on the Apostolate and the Evangelizing Methods of the Mendicant Orders in New Spain: 1523-1572 (University of California Press 1966).

${ }^{79}$ AGUIRRE, G. y POZAS, R. Instituciones indígenas en el México actual, Métodos y Resultados de la Política Indigenista en México, 6 (1954) 171-269.

${ }^{80}$ DUSSEL, E. Caminos de liberación latinoamericana I. Docencia (Buenos Aires 2015) 89.

${ }^{81}$ GONZÁLEZ, Y. Animales y plantas en la cosmovisión mesoamericana. (México 2001) 64.

${ }^{82}$ BÁEZ-JORGE, F.Entre los naguales y los santos (Veracruz 2008) 201.

${ }^{83}$ LÓPEZ, A. y MILLONES, L. Los Mitos y sus Tiempos. Creencias y narraciones de Mesoamérica y los andes (México 2015$) 149$.

${ }^{84}$ DUSSEL, E. Para una ética de la liberación latinoamericana. Tomo II (México 1973) 34.

34 Derecho Animal. Forum of Animal Law Studies, vol. 12/1 
mesoamericano.

La lógica de dominación cristiana sistematizó la totalidad fetichizada que se autointerpretó como absoluta, como un movimiento de expansión de lo mismo, configurando en un momento dialéctico y reductivo a los pueblos y comunidades indígenas en la periferia del no ser, cosificándolos como un objeto que se puede disponer; una vez quitando la dignidad a los pueblos y comunidades de América se le puede manipular, controlar, dominar, torturar y asesinar. ${ }^{85}$ La conquista como movimiento dominador destruyó para siempre las estructuras de la civilización, las antiguas formas de vida y el núcleo social de las culturas prehispánicas. En esta época, la estructura social, económica, política y cultural del indígena es desquiciada para siempre, produciendo una ruptura, un corte radical, una aniquilación del corazón de las antiguas culturas ${ }^{86}$. Estas sociedades sufrieron la máxima tragedia: ver destruidos no ya sólo sus ciudades y sus pueblos, sino los cimientos de su cultura ${ }^{87}$. Pese a esta destrucción sistematizada, muchas expresiones y elementos asociados del jaguar junto con otros conjuntos simbólicos, han logrado sobrevivir hasta la actualidad pese a los procesos del dominio europeo cultural e incluso a factores como prohibiciones eclesiásticas de la época colonial.

Los rituales asociados al jaguar en el periodo de la conquista fueron de tal importancia como elemento de resistencia a la hegemonía cristiana, que las autoridades coloniales prohibieron diversas manifestaciones culturales asociadas a este felino; en Mazatenango, Guatemala, en 1623, existió una prohibición de la danza del "Tun-teleche" o "Loj-tun"; representación conceptual del Rabinal Achí que cuenta con elementos simbólicos asociados al jaguar, prohibición que duraría hasta 1856; en Tamulté de las Sabanas, Tabasco en 1631, prohibieron la danza del tigre, basándose en que estos rituales entregaban ofrendas a "Kantepec", así como por sacrificar gallinas y expresar una representación simbólica del sacrificio de un individuo que era entregado a los tigres. Los caciques entregaban los ídolos y acusaban a los curanderos para ganar el favor de los españoles. Tardó mucho la religión "yokot'an" en resurgir con nuevas prácticas cristianas ${ }^{88}$, en caso de realizar esta actividad que atentaba contra la ideología conquistadora se castigaba a los habitantes con cien azotes, destierro y excomunión. En Chiapas la danza del "calalá", que se asociaba a este felino, tuvo una prohibición de algunos elementos culturales que irritaban a las autoridades religiosas a principios del siglo $\mathrm{XVII}^{89}$. Estas prohibiciones en el contexto inquisitivo de dominación demuestran el carácter sacro del jaguar y como elemento de resistencia, convirtiendose en símbolos subversivos para el nuevo estado virreinal imperante, ya que, como se ha señalado anteriormente, en él se sintetiza, de manera sobresaliente, la sacralidad simbólica nativa de los pueblos americanos ${ }^{90}$.

La estructura de colonización bajo el cristianismo dominador dio pauta a la conjunción de fenómenos sincréticos, paralelismos culturales y desplazamiento, que en el plano histórico marcaron la decadencia gradual y, en algunos casos, la desaparición semiótica de los rasgos prehispánicos, fortaleciéndose de manera proporcional el culto del cristianismo dominador. El paralelismo, el desplazamiento y el sincretismo asumieron diferentes formas, remitiendo la cuestión de este último a las categorías de sincretismo lineal y sincretismo radical ${ }^{91}$ por los procesos de adición, selección, substitución e identificación ${ }^{92}$ de las expresiones en contacto, dando como resultado manifestaciones culturales complejas asociadas al jaguar y otros elementos simbólicos en los pueblos y comunidades de México.

La gran matriz cultural y simbólica que rodean al jaguar en Mesoamérica en el periodo colonial, tuvo una ruptura sin precedentes derivado de la dominación y el despojo del sistema semiótico de los pueblos indígenas, resultando en procesos de desplazamiento, sincretismo y simultaneidad o paralelismo. La destrucción de los antiguos elementos numinosos como "ocelotl" tuvo una relación proporcional con el aumento de la fe cristiana en los pueblos oprimidos. Las expresiones cúlticas resultantes del proceso de la evangelización repercutieron en un ámbito de funcionamiento en ordenes sociales públicos y privados, esta conquista espiritual fue el ropaje religioso, el velo ideológico que cubrió uno de los más gigantescos proyectos etnocidas y genocidas emprendidos en la historia ${ }^{93}$.

\footnotetext{
85 DUSSEL, E. 1492 : el encubrimiento del otro: hacia el origen del mito de la modernidad (1994) Recuperado de http://biblioteca.clacso.edu.ar/clacso/otros/20111218114130/1942.pdf [Última conslta: 20 de octubre 2020].

${ }^{86}$ DUSSEL, E. Historia general de la iglesia en América Latina. Tomo I : introducción general a la historia de la iglesia en América Latina (México 1983).

${ }^{87}$ Véase LEÓN-PORTILLA, M. Visión de los vencidos (México 1959).

${ }^{88}$ URIBE INIESTA, R. y MAY MAY, B. T'an i K'ajalin Yokot'an Palabra y pensamiento Yokot'an (México 2000).

${ }^{89}$ NAVARRETE, F. Prohibición de la danza del Tigre en Tamulté, Tabasco en 1631, Tlalocan, 4 (1971) 374-376. Recuperado de: https://revistas-filologicas.unam.mx/tlalocan/index.php/tl/article/view/271 [Última consulta: 01 de noviembre 2020].

${ }^{90}$ RAMÍREZ, J.L. El jaguar transformado. Una hipótesis poliédrica a propósito de la danza "El caballito blanco". Estudios de cultura maya, 40 (2012).

${ }^{91}$ BASTIDE, R. El prójimo y el extraño. El encuentro de las civilizaciones (Buenos Aires 1973).

${ }^{92}$ BÁEZ-JORGE, F. Los oficios de las Diosas (Dialéctica de la religiosidad popular en los grupos indios de México) (Veracruz, 2000) 183.

${ }_{93}$ BÁEZ-JORGE, F. Los oficios de las Diosas (Dialéctica de la religiosidad popular en los grupos indios de México) (Veracruz, 2000) 186 y ss.
} 
Como resultado de la transformación radical de los valores simbólicos de una cultura a otra, en la praxis cultural se va a declarar una persecución en contra de los jaguares. Este asedio del jaguar ante la dominación europea, se puede encontrar en las crónicas y estudios de los historiadores europeos en América. Esta persecución se refleja en lo descrito por Fray Francisco Ximénez en su obra denominada Historia Natural del Reino de Guatemala, donde menciona que el tigre -que era como se le nombraba al jaguar- era un animal dañino para el ganado y la gente, por lo que se pedía destruir a este animal ${ }^{94}$. Asimismo, narra en el primer tercio del siglo XVIII cómo el jaguar es aprensado cuando se sube a los árboles, huye de los perros por miedo, mencionando que cualquier indio, como tenga perro lo mata. De acuerdo a Gonzalo Fernández de Oviedo, la concepción del conquistador sobre el jaguar es que este felino se mataba muchas veces fácilmente por los ballesteros en compañía de un can pequeño ventor o sabueso. Fernández describe lo siguiente: "El año de 1522 años yo y otros regidores de la ciudad de Santa María del Antigua del Darien hicimos en nuestro cabildo y ayuntamiento una ordenanza, en la cual prometimos cuatro o cinco pesos de oro al que matase cualquiera tigre de éstos, y por este premio se mataron muchos de ellos en breve tiempo, de la manera que es dicho, y con cepos asimismo" $"$.

Fray Toribio de Benavente, Motolinía, menciona que en el pueblo de Chocamán en Veracruz, México, tigres y leones (jaguares y pumas) fueron asechados por perros traídos de Castilla con la finalidad de defender y conservar a los indios de los españoles, matando 110 felinos, en otro pueblo de Veracruz, denominado Amatlán con dos perros de España, mataron a 120 leones y tigres. Asimismo, fray Toribio menciona que tigres y leones han comido mucha gente, lo cual no solían hacer antes que los españoles viniesen, incluso narra cómo el jaguar en alguna ocasión liberó a los "mansos indios" del yugo de un español que cruelmente los trataba ${ }^{96}$ posicionando al jaguar como un ente liberador. La visión errada del felino asesino de humanos, tiene una importancia vital en el asedio del jaguar por la dominación española ya que este felino no supone un peligro a la integridad física de los humanos, solamente es necesaria la cautela cuando hay encuentros de humanos con jaguares: I) hembras con crías, II) jaguares con presas recién cazadas, III) machos con hembras en celo ${ }^{97}$ y IV) cuando se ataca a este ejemplar y pelea por su vida. El jaguar difiere de los patrones conductuales de sus parientes en el Viejo Mundo, ya que en ninguna parte de México existen casos confirmados de muertes de personas por ataque de jaguares. Algunos hombres indudablemente han sido atacados por algún jaguar acosado o acorralado, pero los ataques sin provocación son $\operatorname{raros}^{98}$. Podemos aseverar que los ataques de jaguares a humanos, que se potenciaron en el periodo de la conquista y que incluso existen en la actualidad, fueron un mecanismo de defensa para pelear por su vida ante su muerte inminente por la cacería sistematizada de esta especie que se perpetuará por siglos en México.

En septiembre de 1493, durante el segundo viaje de Cristóbal Colón hacia América, se transportaron entre los animales esclavizados bajo el proceso de domesticación uno de los elementos de la biota europea que ha propiciado la extinción de cientos de especies silvestres y que fue una pieza importante de la dominación europea: los perros. Estos perros de guerra como los describe Pedro Martír de Anglería ${ }^{99}$ eran principalmente mastines y galgos (lebreles) pura raza ${ }^{100}$. Los perros provenientes de Europa generaron un cambio sustancial posicionándose como la principal arma de combate de los españoles ${ }^{101} \mathrm{y}$ como instrumento de represión y castigo hacia los pueblos indígenas; ya que fueron enseñados y amaestrados por los españoles como perros bravísimos y ferocísimos para matar y despedazar indios, estos actos los consideró Bartolomé de las Casas como uno de los sucesos más crueles e infernales en la Nueva España ${ }^{102}$. Cristóbal Colón en su cuarto viaje cuando llega a Cariay, ahora Costa Rica, narra que existían animales menudos y grandes, traía consigo perros de Irlanda que con los ballesteros realizaron montería dando muerte a diversos animales como los leones ${ }^{103}$ (jaguares y pumas).

\footnotetext{
${ }^{94}$ XIMENEZ, F. Historia Natural del Reino de Guatemala, (Guatemala, 1967) 52-55.

95 FERNÁNDEZ DE OVIEDO, G. Sumario de la natural historia de las Indias (México 1950) 143-148.

${ }^{96}$ DE BENAVENTE, T. Historia de los Indios de la Nueva España. Real Academia Española. Centro para la Edición de los Clásicos Españoles (Madrid 2014) 148 y ss.

${ }^{97}$ HOOGESTEIJN, R., HOOGESTEIJN, A., TORTATO, F., PAYÁN, E., JEDRZEJEWSKI, W., MARCHINI, S., VALDERRAMA, C. \& BOEDE, E. Consideraciones sobre la peligrosidad del jaguar para los humanos: ¿quién es letal para quién? En II. Conflictos entre felinos y humanos en América Latina (Colombia 2016) 445-466.

${ }^{98}$ STARKER LEOPOLD, A. Fauna Silvestre de México. (California 1959) 527-534.

${ }^{99}$ MÁTIR DE ANGLERÍA, P. Décadas del Nuevo Mundo (Buenos Aires 1944).

${ }^{100}$ BUENO JIMÉNEZ, A. (2011). Los perros en la conquista de América: historia e iconografía. Chronica Nova. Revista De Historia Moderna De La Universidad De Granada, 37 (2017) 177-204. Recuperado de https://www.semanticscholar.org/paper/Los-perros-enla-conquista-de-América\%3A-historia-e-jiménez/c7a54f952839dbd211ea7cc8637d776b1c8c4149 [Última consulta:30 de sepriembre 2020]

${ }^{101}$ DE LAS CASAS, B. Historia de las Indias. Tomo III.

https://www.argentina.gob.ar/sites/default/files/historia_de_las_indias_1_de_las_casas.pdf [Última consulta: 30 septiembre 2020].

102 DE LAS CASAS, B. Brevísima relación de la destrucción de las Indias (Madrid 1993) 172 y ss.

${ }^{103}$ COLÓN, C. Los Cuatro Viajes del Almirante y su Testamento (España 1980) 199.

36 Derecho Animal. Forum of Animal Law Studies, vol. 12/1
} 
Desde un enfoque ecológico, los perros que introdujeron los españoles potenciaron la aniquilación de la fauna silvestre nativa americana por diversos factores, siendo uno de los principales que este animal se convirtió en un elemento indispensable en la cacería. Si bien existían en Mesoamérica distintas clases de perros que convivían con diversos grupos indígenas, estos tenían una relación multifacética: era un símbolo religioso y fue considerado desde el compañero que sustituye al humano ante los dioses en el sacrificio y que lo lleva a su destino final, hasta el antepasado y el héroe cultural que le da el fuego solar y, con él, la civilización. El perro está en el origen del hombre, en su vida cotidiana y en su muerte ${ }^{104}$. Con referencia a la cacería, el perro prehispánico mesoamericano no era un elemento cotidiano en esta práctica, no existen referencias sobre la utilización de perros para la caza, tampoco se han encontrado imágenes asociadas a la cacería en el corpus mesoamericano. Solamente se narran como técnicas de cacería: el uso de lazos, redes, trampas, atrayentes, disfraces y, la más difundida en Mesoamérica, que consistía en una cacería colectiva donde muchas personas rodeaban un cerro y subían lentamente hacia la cúspide, donde se acorralaba a distintos animales. Entre las armas que se utilizaban, sobresalen el arco con flechas y el "xonecuilli", una especie de propulsor ${ }^{105}$. Fue con la llegada del perro extranjero y el uso de armas europeas como empieza el declive simbólico biocultural de la fauna silvestre, en específico del jaguar, ya que su caza se potenció en todo su ámbito de distribución.

Durante más de 5 centenarios, desde el inicio del avasallamiento español a la actualidad, se van a perfeccionar las técnicas cinegéticas para asesinar jaguares con métodos como la lampareada, batida con perros especializados ${ }^{106}$, venenos, trampas y el asecho especializado. Estas herramientas bélicas van a diezmar la población de jaguares a niveles críticos. Las cifras de jaguares asesinados en este periodo son muy escasas y existe poca literatura al respecto, de acuerdo a Alexander Humboldt, a principios de 1800 se exportaban 2 000 pieles de jaguar por año desde el puerto de Montevideo ${ }^{107}$. En este periodo aproximadamente 4000 jaguares eran cazados al año para ser exportados a Europa ${ }^{108}$. Estos fenómenos sociales de aniquilación representaron el inicio del detrimento exponencial biocultural en una escala continental del jaguar.

\subsection{Moda, alta costura y aniquilación}

Otro punto cúspide de afectación al jaguar se da en la historia moderna que incluye la era del capital, la era del imperio y el siglo XX, con una decadencia acentuada a mediados del siglo XX. En este lapso de tiempo, en una escala continental, se llevó a cabo una intensa matanza sistematizada de jaguares y felinos silvestres por la industria de la moda donde se mercantilizó el uso de pieles de felinos manchados como vestimenta en el primer mundo; América del Norte y Europa ${ }^{109}$. Miles de jaguares eran cazados legalmente como parte del mercado internacional de pieles, basados en la confección de su piel para elaborar artículos de moda, principalmente abrigos. Si bien la cacería del jaguar había tenido una fuerte relación con el uso de su piel que datan de épocas antiquísimas, en este periodo se potenció esta actividad a nivel global afectando severamente sus poblaciones, ya que la matanza fue brutal e implacable ${ }^{110}$.

Se estima que se extraían de la Amazonía brasileña hasta 15000 jaguares y 80000 ocelotes cada año a finales de la década de los años 60 e inicios de $\operatorname{los} 70^{111}$. Las estimaciones de las importaciones anuales para este período, en Estados Unidos y Europa indican que anualmente llegaban al mercado pieles de más de 15 000 jaguares y 200000 ocelotes donde se incluían otras especies pequeñas similares como el tigrillo o el jaguarundi ${ }^{112}$. En México 1300 pieles de jaguar y 15000 de ocelote y tigrillo fueron exportadas legalmente a

\footnotetext{
${ }^{104}$ DE LA GARZA, M. El perro como símbolo religioso entre los mayas y los nahuas. Estudios de cultura Náhuatl, 27, (1997) Recuperado de: http://www.historicas.unam.mx/publicaciones/revistas/nahuatl/pdf/ecn27/519.pdf [Última consulta: 23 septiembre 2020].

105 OLIVIER, G. Cacería, sacrificio y poder en Mesoamérica. Tras las huellas de Mixcóatl, "Serpiente de Nube” (México 2015).

${ }^{106}$ El dogo argentino es una raza de perro diseñado por Antonio Nores Martínez en el sur del continente americano, quien buscaba un animal adecuado para la caza mayor de especies habituales en Argentina. Véase NORES, A. El dogo argentino (Argentina 1982).

${ }^{107}$ CABRERA, A. y YEPES, J. Mamíferos Sud-americanos. Historia Natural Ediar, Compañía Argentina de Editores (Buenos Aires 1940) 370 y ss.

${ }^{108}$ GUGGISBERG, C. Wild cats of the world. Taplinger (New York 1975).

109 GIETELING, C. Jaguar en Ocelot: Biologies, Bedreiging en Bescherming. The Netherlands: Unpublished Report for WWF Germany (Frankfurt 1972), FITZGERALD, S. International wildlife trade: whose business is it? World Wildlife Fund. (Washington, D. C. 1989) 459; RUÍZ-GARCÍA, M., PAYÁN, E., MURILLO, A. y ÁLVAREZ, D. DNA micro-satellite characterization of the jaguar (Panthera onca) in Colombia. Genes, Genetics and Systematics 81 (2006) 115-127; PAYÁN, E y TRUJILLO, L. A.The Tigrilladas in Colombia. Cat News 44 (2006) 25-28.

${ }^{110}$ CEBAllOS, G. LIST, R. MEDELlín, R., BONACIC,C. y PACHECO, P. Los Felinos de América. Cazadores sorprendentes. (México 2010) 157.

${ }^{111}$ SMITH, N.J.H. Spotted cats and the Amazon skin trade. Oryx 13 (1976) 362-371. Recuperado de DOI: https://doi.org/10.1017/S0030605300014095 [Última consulta: 30 noviembre 2020].

112 FITZGERALD, S. International wildlife trade: whose business is it? World Wildlife Fund. (Washington, D. C. 1989) 333; NOWELL, K. y JACKSON, P. Wild Cats: Status Survey and Conservation Action Plan (Pennsylvania 1996) 223.
} 
Estados Unidos de América entre 1968 y 1970, miles más fueron exportadas ilegalmente ${ }^{113}$.

La matanza de jaguares tomó un fuerte posicionamiento comercial por la industria de la moda, ya que prácticamente en todas las zonas donde se distribuía esta especie tuvo un crecimiento exponencial de demanda peletera. A manera de ejemplo, en algunas regiones del sur de México y Guatemala, en la década de los años setenta, los grupos rurales por casi una década realizaron esta actividad que nombraron como la tigreada, al mismo tiempo se convirtió en una alternativa de trabajo con un ingreso estable ${ }^{114}$. Estas actividades se generalizaron en todo el ámbito de distribución de este felino en América y todavía en la actualidad se practican, si bien tuvo un impacto en la economía social local, este no fue significativo, donde sí tuvo un impacto trascendental fue en la industria de la alta costura. Analizada desde un enfoque social, la industria de la moda tendrá como elemento germinal las obras realizadas por Frederick Worth en el siglo XIX. Este diseñador fue uno de los impulsores de la alta costura, donde la moda accede a la era moderna, convirtiéndose en una empresa de creación, pero también en espectáculo publicitario ${ }^{115}$.

La moda aniquiladora que confecciona pieles de felinos silvestres, afectó gravemente al jaguar ya que maximizó su materialización y reducción a un objeto, atribuyéndole elementos intangibles y una gran carga de significaciones novedosas asociadas a este "objeto", principalmente aquellas asociadas al prestigio y a la superioridad de la burguesía. En el primer momento de la moda industrial, la alta costura configuró el uso de pieles de felinos silvestres como reservados para determinada facción de la sociedad, este uso será denominado haute fourrure, que representa la alta piel confeccionada por esta industria. La ejemplificación de esta acción de opresión hacia los felinos con patrones asociados a rosetas y manchas por la industria de la moda, la observamos en la vestimenta de alta piel, usada por Jacqueline Kennedy, esposa del expresidente de Estados Unidos, John F. Kennedy, quien desde 1962 empezó a mostrar el uso de prendas con piel de tigre, leopardo, cheetah y jaguar ${ }^{116}$.

Algunos de los grandes representantes de la alta costura como Gucci y Fendi tienen sus orígenes en la industria peletera, quienes posteriormente se convirtieron en sinónimo de clase alta, incluso más que de moda ${ }^{117}$. La ropa y el vestir han sido regulados históricamente de acuerdo con el género y la sexualidad, así como con lo social, es decir, la clase, la distinción ${ }^{118}$ y la estructura jerarquizada. En la jerarquía de las pieles y de las posiciones sociales creadas por estos actos reguladores, también influyeron en los conceptos de propia sexual entre las distintas clases de mujeres. En ciertas épocas, incluso se prohibió a las prostitutas que llevarán pieles, a fin de diferenciarlas de las denominadas mujeres respetables ${ }^{119}$.

Con la moda abierta, considerada el arte de las pequeñas diferencias y sutilezas de la apariencia ${ }^{120}$, en esta manifestación de la industria de la moda, la personalización será lo que cuente. Pese a que este tipo de moda sobresale de la alta costura, el jaguar seguirá siendo considerado un elemento trascendental en la industria, ya que la sociedad de consumo continuará potenciando el uso de pieles de este felino y se crearán múltiples formas de objetivarlo, una de ellas será reducirlo para su uso como mascota.

Este felino seguirá siendo considerado un objeto vinculado a la necesidad colectiva germinada en la moda y la simbolización del gusto, ya que estandariza una jerarquía de gustos -algunos sectores de esta élite incluso lo confeccionan como una marca y emblema- perpetuando una visión simbólica de poder de las élites que se encuentran en la cima de la estructura social para diferenciarse de los demás. Esta estructura hace que las clases inferiores y populares tengan en su desarrollo un vínculo para apropiarse y reproducir el gusto de las clases dominantes. Estas sociedades tendrán sus manifestaciones culturales y estéticas propias, incluso arroparán a este felino como marca y emblema en sus entornos cotidianos, sin tener un vínculo directo con las sociedades de élite.

En los momentos históricos de la moda, la alta costura será transformada hacia una industria de masas adecuada a la sociedad de consumo, donde es necesaria una moda abierta siendo un periodo importante el prêt-à-porter (listo para llevar), donde la figura del jaguar seguirá teniendo un valor preponderante en esta época, potenciando la demanda diversificada de partes de este animal (principalmente dentición, garras y piel).

La industria de la moda creó un simbolismo basado en el capital y las sociedades de consumo, lo que encubrió aún más al sujeto-jaguar en mercancía-jaguar, asimismo, este fenómeno invisivilizó su espacio simbólico proveniente de los entornos rurales de América. Esta hegemonía sociocultural proveniente del extranjero, propició una nueva ruptura en la relación humano-jaguar. La reducción al valor de uso y valor de

\footnotetext{
113 CEBALLOS, G. Los felinos de América (Mexico 2010) 23.

${ }^{114}$ RODAS, I. Colonización, cacería y territorio en el Usumacinta Medio, Guatemala en Uso y manejo de Fauna Silvestre en el norte de Mesoamérica (Veracruz, 2010) 315-350.

${ }^{115}$ LIPOVETSKY, G. El imperio de lo efímero. Moda y su destino en las sociedades modernas (Barcelona 1990) 79 y ss.

${ }^{116}$ NOWELL, K. y JACKSON, P. Wild Cats: Status Survey and Conservation Action Plan (Pennsylvania 1996) 224.

${ }^{117}$ RIELLO, G. Breve historia de la de la moda. Desde la Edad Media hasta la actualidad. (Barcelona 2016) 132.

118 ENTWISTLE, J. El cuerpo y la moda. Una visión sociológica (Buenos Aires 2002) pp. 171 y ss.

119 EMBERLEY, J. Venus and Furs: The Cultural Politics of Fur. (Cornelle University Press 1999) 9.

${ }^{120}$ LIPOVETSKY, G. El imperio de lo efímero. Moda y su destino en las sociedades modernas (Barcelona 1990) 70.

38 Derecho Animal. Forum of Animal Law Studies, vol. 12/1
} 
cambio de esta especie, hizo que la relación utilitaria tuviera un fuerte apego a lo económico. El jaguar reducido a objeto de moda salvaje, exótico y místico, será una prenda que cobra fuerza por su valor de cambio derivado del trabajo de las casas de moda y las industrias.

La utilización de jaguares vivos o el uso de sus partes en la industria de la moda representa la máxima transformación del jaguar en mercancía objeto-cosa-propiedad, alejando y encubriendo dimensiones ontológicas de su ser y esencia. Como se ha señalado, el jaguar y su piel tuvieron un fuerte impacto en la industria de la moda que arrebató y redujo a este animal y sus partes en propiedad, clasando de buen y distinguido gusto el uso de sus partes (principalmente piel, dentición, huesos, grasa, órganos, sangre y garras) y su esclavitud como mascota. Al mismo tiempo de clasante de quienes usaban estos materiales y consagrando una jerarquía social. Esto generó todo un complejo sistema económico de oferta y demanda del producto, formulándose el gusto asociado a la cosificación, aniquilación, esclavitud y mercantilización del jaguar. Se trata del conjunto de prácticas y propiedades de una persona o de un grupo, son el producto de un encuentro (de una armonía preestablecida) entre bienes y un gusto ${ }^{121}$. El dinamismo de la industria de la moda propició el desplazamiento del polo dominante al polo dominado en la confección de la piel del jaguar que tuvo una producción importante en la peletería, donde se reprodujeron objetos de moda de jaguar de origen popular (Imagen 3) e incluso el desplazamiento, aunque también se ha instrumentado en la cosificación del jaguar como mascota, principalmente de grupos pertenecientes al crimen organizado.

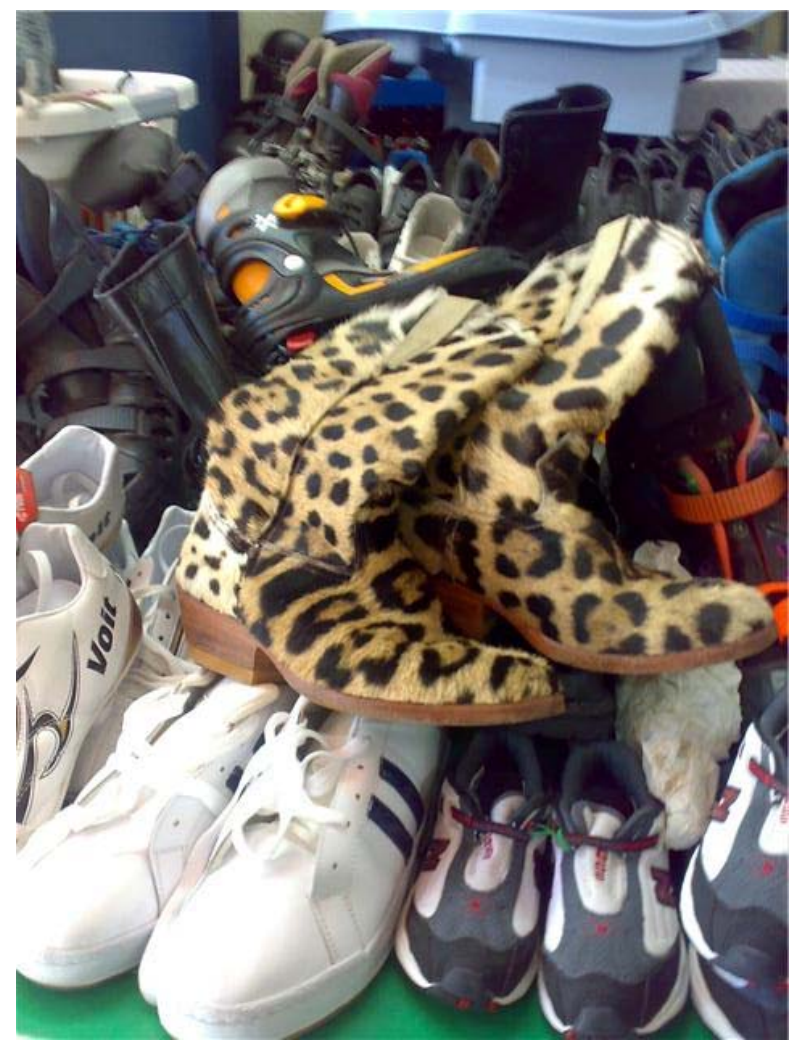

Imagen 3. Venta de botas confeccionadas con piel de jaguar en el estado de Hidalgo, México (2008). Este producto no tenía marca lo que delimita su fabricación de origen popular, artesanal (Fuente: fotografía de Jonatan Job Morales García. Cortesía de Biofutura A.C.)

\subsection{Conservación y capital en la aniquilación del jaguar}

El jaguar al entrar socialmente en la estructura mercantilista, la oferta y la demanda de este ser se exponenció. Los encargados de conseguir estas especies silvestres y confeccionarlas -agentes de la producción- tuvieron gran provecho económico por la reducción y el sufrimiento de los animales usados en la industria de moda para atender a la demanda y satisfacer la absurda necesidad surgida por la moda. Esta mercantilización se rigió por la cacería en un primer momento, posteriormente se industrializó este proceso a través de la cosecha de su producción y el manejo sistematizado de cautiverio -términos acuñados por la industria y mercantilización del jaguar-, tanto en espacios naturales semiabiertos como en encierros bajo una falsa concepción del desarrollo sostenible. Esto tendrá una finalidad dual y complementaria; el primero es aumentar la producción y reducir costos y la segunda será para mantener poblaciones viables y continuar con 
la subministración de productos al servicio del capitalismo voraz. Esto debido a que las poblaciones tendrán un declive en espacios silvestres poniendo al jaguar en peligro de extinción. Todo ello es un reflejo de cómo la conservación de la fauna silvestre al servicio del capital crea una (i)racionalidad capitalista de la conservación, que desde un falso enfoque cientificista valida todas las atrocidades que se realizan contra la naturaleza. Esta (ir)racionalidad capitalista transforma a la naturaleza en recursos naturales, asimismo, desde el cientificismo del capital en un enfoque semántico se re-objetiviza al jaguar al establecer mecanismos para su cosecha, término usado por la arcáica escuela de conservación al servicio del capital para delimitar la reproducción de esta especie para su uso. Otro término cosificador es el de manejo, que nace desde la visión del valor del uso del jaguar para la cacería -game manegment-, manejo del juego; el juego recreacional será asesinar a los animales, posteriormente se aperturó el termino para incluir otras modalidades de uso y aprovechamiento, entendiéndose desde esta visión que manejo de fauna es el arte de usar la tierra para producir cosechas sostenidas anuales de animales silvestres con fines recreacionales ${ }^{122}$.

Los términos de la arcaica escuela de conservación al servicio del capital repercuten ahora desde dimensiones aparentemente científicas, sumergiéndose en una profunda mercantilización que transforma ontica y ontológicamente como mercancía cosa-objeto frente a la demanda de los consumidores por sus gustos objetivados, invisibilizando aún más el ser y la esencia de esta especie. Esta visión irracional de la conservación que convierte la vida silvestre en un activo comercial y opta por la muerte de los animales a través de la cacería ${ }^{123}$-, como una opción para la supervivencia de los animales es el reflejo de la ciencia irrracional al servicio del capital. El jaguar en los planos sobreestructurales es dominado hegemónicamente con funciones organizativas y conectivas, donde los intelectuales orgánicos del grupo dominador son gestores para el ejercicio de las funciones subalternas de la hegemonía social y del gobierno político ${ }^{124}$.

El discurso del desarrollo sostenible ha colonizado a la naturaleza, convirtiéndola en capital natural ${ }^{125}$, propiciando una degradación ambiental y una apropiación de la naturaleza bajo superlativos económicos. Siguiendo a Marcuse, "en el desarrollo de la racionalidad capitalista, la irracionalidad se convierte en razón: razón como desarrollo desenfrenado de la productividad, conquista de la naturaleza, ampliación de las masas de bienes; pero irracionalidad porque el crecimiento de la productividad, del dominio de la naturaleza y de la riqueza social se convierten en fuerzas destructivas" ${ }^{126}$. Las acciones de conservación al servicio del capital creará una falsa apreciación de la realidad por contener representaciones subjetivas, alejándose del conocimiento científico que busca la producción de los conceptos -del concreto de pensamiento-, que permiten la aprehensión cognoscitiva de lo real ${ }^{127}$. Pensar a una especie animal cognoscitivo-racional como objeto-cosa y crear todo un andamiaje para su mercantilización a costa del sufrimiento y su aniquilación; es una irracionalidad que tendrá que ser denunciada y combatida. La matanza y la justicia no pueden vivir juntas ${ }^{128}$, en palabras de Isacc Singer: no habrá justicia mientras el hombre empuñe un cuchillo o un arma de fuego para aniquilar a aquellos más débiles que él ${ }^{129}$.

La reducción de este felino como propiedad y las prácticas especistas en torno a él, permiten adentrarse a las condiciones en que se desarrolla el andamiaje de la reducción como objeto a través de la sistematización de la infraestructura, estructura y la superestructura ${ }^{130}$ social que sustenta y legitima la dominación hacia el jaguar, teniendo en una de sus aristas de dominación basada en el gusto, trasfigurando un valor de cambio ${ }^{131}$. Esta trasformación hace que el jaguar sea un elemento mercantil, producto de las invenciones históricas antes señaladas. El gusto por la mercantilización del jaguar y su reducción como objeto en un sistema de clasamiento, visibiliza la cosificación de este ser en el sistema capitalista, encontrándose profundos elementos entre la oferta y la demanda que persisten en la actualidad.

\subsection{Dinamismo y resistencia en la dominación}

\footnotetext{
122 LEOPOLD, A. Game management (New York 1933) 481.

${ }^{123}$ Véase LEWIS, D., y ALPERT, P. Trophy hunting and wildlife conservation in Zambia. Conservation Biology 11 (1997) 59-68, https://doi.org/10.1046/j.1523-1739.1997.94389.x [Ưltima consulta: 27 de noviembre 2020] ROSAS ROSAS, O. y NÚÑEZ R. Jaguar y puma, en Ecología y Manejo de Fauna Silvestre en México (México 2014) 349.

${ }_{124}$ Véase GRAMSCI, A. Para la reforma moral e intelectual (Madrid 2016) 154-164.

${ }^{125}$ LEFF, E. Ecología y Capital. Racionalidad ambiental, democracia participativa y desarrollo sustentable (México 1994$) 352$ y ss.

${ }^{126}$ MARCUSE, H. "Industrialization and capitalism in the work of Max Weber", Negations, (New York, 1972) 207.

127 Veáse LEFF, E. Ecología y Capital. Racionalidad ambiental, democracia participativa y desarrollo sustentable (México 1994) 30.

128 TELUSHKIN, J. Jewish Wisdom: Ethical, Spiritual, and Historical Lessons from the Great Works and Thinkers. (New York 1994) 450 y ss.

${ }^{129}$ GIEHL, D. Vegetarianism: A Way of Life (foreword by Isaac Bashevis Singer) (New York 1979).

${ }^{130}$ Véase MARX, K. ENGELS, F. La ideología alemana. Crítica de la novísima fillosofía alemana en las personas de sus representantes Feuerbach, B. Baauer y Stirner y del socialismo alemán en las de sus diferentes profetas (Barcelona 1974) 229-236, MARX, K. El capital. El porceso global de la producción capitalista. Tomo III (México 1977), ALTHUSSER, L. y BALIBAR, E. Para leer El capital. (México 1970) 145 y 202.

${ }^{131}$ Véase MARX, K. El capital: Crítica de la economía política. Tomo I. El proceso de producción del capital. (México 2014).

40 Derecho Animal. Forum of Animal Law Studies, vol. 12/1
} 
La sociedad de consumo en la industria de la moda asociada a la esclavitud del jaguar, si bien se presenta como agente de dominación en el seno de esta sociedad, también presentará rupturas y puntos de resistencia formados principalmente por los grupos defensores de animales y algunos conservacionistas. Esta hegemonía de dominación tendrá un límite al poner en peligro de extinción a esta especie, incluso, en muchos espacios naturales se le extirpó por completo. Esta pérdida de individuos en el medio silvestre, fue la base para que en 1975 se prohibiera como regla general su comercio por estar enlistado en el apéndice I de la Convención sobre el Comercio Internacional de Especies Amenazadas de Fauna y Flora Silvestres (CITES). Posteriormente regionalizado en México, en 1987 se decretará una veda indefinida ${ }^{132}$, sin embargo, esta veda será rebasada por la voracidad del capital, lo cual generó un mercado del jaguar como mascota autorizado por las autoridades ambientales.

La lucha por los derechos de los animales en la industria de la moda ha hecho que importantes casas de moda e industrias como Versace, Gucci, Prada, Lacoste, Michael Kors, Nautica, Zara, Armani o Hugo Boss decidan no usar la piel de animales silvestres en sus prendas, incluso la firma homónima Karl Lagerfeld quien era un gran defensor del uso de pieles para la industria de moda, anunció en 2019, el cese del uso de pieles de animales en sus colecciones.

Eliminar el uso de pieles en la industria de la moda deriva de los cambios externos que hicieron época, principalmente por la resistencia y esfuerzo del movimiento de las asociaciones en defensa de los derechos de los animales, sincronizándose revoluciones internas con elementos externos, dando pauta a una moda sustentable sin pieles de animales silvestres. Esto, prima facie, es una victoria de los movimientos en pro de los animales, empero, actualmente sigue el uso de jaguares, develando así que el campo no se eliminó y solamente se modificó, ya que sigue existiendo la dominación por considerarse un accesorio vivo como mascota y el comercio existe en la ilegalidad. La dominación hacia esta especie se ha reestructurado y seguirá siendo un objeto de moda, de buen gusto que, si bien se modificará de contenido, la estructura de dominación y cosificación permanecerá estructuralmente idéntica, como un emblema de clase; quien quiera tener un jaguar, tendrá que pagar una gran cantidad de dinero y así, reflejará su poder adquisitivo ante las masas. Es el campo de la dominación-enajenación que cosifica y convierte en un objeto al jaguar es el que se necesita destruir.

La reducción del jaguar a objeto de mercado, invisibiliza lo que en realidad es: un ser con capacidades cognoscitivas y con derechos asociados a su vida y libertad. Atentar contra estos elementos es reflejo del especismo brutal que ha puesto al borde de la extinción a esta y otras tantas especies. El elemento continuo que impulsa que este felino no escape del campo de la dominación y que este sistema complejo funcione, es la creencia colectiva sobre su relación con el poder o más bien, se debe al desconocimiento colectivo, ya que el comercio de las pieles, en la medida en que es suministro de prendas ornamentales, para quienes no tienen ninguna necesidad de llevarlas, así como la esclavitud de un ser para diversión, es un negocio bárbaro y estúpido $^{133}$. La ideología de la sociedad de consumo que reduce al jaguar a un objeto se basa en el engaño y en la mistificación como bien sagrado del jaguar-producto que en los ciclos de consagración categoriza y establece una de las bases para conformar la jerarquía social.

\subsection{Las postrimerías del siglo XX y el introito de la dominación en el siglo XXI}

En México, el pensamiento asociado a la destrucción y aniquilación lícita del jaguar, se fortaleció en los 457 años consistentes entre el periodo colonial, hasta la declaración de la veda de esta especie en 1987, por lo que existe una carga antiquísima asociada a un pasado cinegético lícito y moralmente aceptable de exterminio, donde el aparato jurídico social permitía ejercer el dominio y destrucción como mecanismos de poder sobre esta especie, evolucionando a una dominación para satisfacer una demanda de las sociedades de consumo modernas.

Tres décadas de laxa protección son insuficientes para enfrentar este pasado de dominación, que tiene como sustento una violencia sistemática en contra del jaguar que en la actualidad continúa manifestándose y que se potencializa materialmente con el flujo constante de armas de fuego en México provenientes principalmente por la frontera norte del país derivado del conflicto con el narcotráfico. Aunado a que este sector se ha inmiscuido en la moda aniquiladora del jaguar, obteniendo incluso ejemplares de esta especie

\footnotetext{
${ }^{132}$ Véase SEDUE. Secretaría de Desarrollo Urbano y Ecología. Acuerdo por el que declara veda indefinida del aprovechamiento de la especie jaguar (panthera onca) en todo el territorio nacional, quedando en consecuencia estrictamente prohibida la caza, captura, transporte, posesión y comercio de dicha especie. Abril 23 de 1987. Recuperado de

http://www.dof.gob.mx/nota_to_imagen_fs.php?codnota=4651536\&fecha=23/04/1987\&cod_diario=200242 [Última consulta: 5 enero 2021].

${ }^{133}$ SALT, H. Los derechos de los Animales (Madrid 1999) 84.
} 
para sus narco-zoológicos y como mascota ${ }^{134}$ y en diversos casos, aún como accesorio en vestimentas. Actualmente el narcotráfico ha arropado el simbolismo del jaguar en sus operaciones, un ejemplo es el grupo de sicarios denominado: los jaguares, que operan en el norte de México. Este grupo es una subdivisión del cártel de Sinaloa o del Pacífico y está identificado como uno de los más violentos y sangrientos de los últimos tiempos. Esta aberración de la narco-cultura refleja el dinamismo de la dominación del jaguar y el desplazamiento del polo dominante al polo dominado donde las clases inferiores y populares tienen en su desarrollo un vínculo para apropiarse y reproducir el gusto de las clases dominantes bajo inmundas y miserables manifestaciones culturales aniquiladoras del jaguar.

\section{Conclusiones}

El campo especista hegemónico de las relaciones objetivas entre individuos e instituciones que están aniquilando al jaguar, presenta cambios en su estructura de dominación sin poner en cuestión al campo mismo de la dominación hacia esta especie. Los espacios de producción de bienes y el espacio de producción de gustos, de manera simétrica, se modifican con la creciente demanda social de proteger a los animales basándose en la bioética, la etología y los derechos de los animales ${ }^{135}$. Los dominados, los pueblos exiliados en la periferia y los actores sociales luchan en resistencia a fin de abatir la dominación del jaguar para hacer época, y al mismo tiempo, desarticular el statu quo. Mientras haya lucha por la liberación del jaguar, existe la esperanza.

El conflicto humano-jaguar se sostiene en una moral de error, esta visión general del mundo que trasciende la muerte de un ser, su cosificación y esclavización al servicio del capital no es más que el producto de factores humanos de dominación. La historia social de la aniquilación del jaguar establece sus fundamentos propios, haciendo la genealogía de la aparición de su objeto como realidad específica y establece en qué momento se habla de la aniquilación, es decir, cuándo se constituye un campo sistematizado en cuyo interior está constituida la relación asimétrica de destrucción del otro -felino- y que se refleja en una gama amplia de prácticas cuyo objetivo es el mismo: aniquilar al jaguar, consagrándose toda una cultura de dominación especista como valor moral.

La relación conflictual Homo sapiens-Panthera onca desde una perspectiva diacrónica muestra que el conflicto, como fenómeno socioambiental, tiene como cimiento interior al especismo con piezas clave del andamiaje social que se exteriorizarán en: 1) explotación y dominación por el ejercicio del poder, 2) intereses económicos basados en: a) transformación en mercancía objeto-cosa asociado al valor de uso y valor de cambio, b) afectaciones al capital, 3) competencia con cazadores y 4) miedo y desconocimiento. La perspectiva histórica conflictual de estas dos especies son la base para la comprensión del fenómeno actual de aniquilación del jaguar en México que, en algunas sociedades, se siguen replicando.

\section{Agradecimientos}

Agradecemos a todo el equipo de Biofutura A.C. y al apoyo emitido por Animal Charity Evaluators, sin ellos, no podría ser posible este trabajo.

\section{Bibliografía}

- AGUIRRE BELTRÁN, G. y POZAS, R. Instituciones indígenas en el México actual, Métodos y Resultados de la Política Indigenista en México, 6 (1954).

- ALATORRE, D. El rito para acceder al cargo de Ajpop entre los k'iche's de Q'umarkaj. Estudios de cultura maya (México 2019).

- ALTHUSSER, L. y BALIBAR, E. Para leer El capital. (México 1970).

- ANDERS, F., JANSEN, M. y REYES L. Crónica mixteca. El rey 8 Venado, Garra de Jaguar, y la dinastía de Teozacualco, Zaachila. Libro explicativo del llamado códice Zouche-Nuttall (México 1992).

- ARROYO-CABRALES, J. Registro Fósil del Jaguar en El jaguar en el nuevo milenio. (México 2002).

- BÁEZ-JORGE, F. Los oficios de las Diosas (Dialéctica de la religiosidad popular en los grupos indios de México) (Veracruz, 2000).

\footnotetext{
${ }^{134}$ Véase MONTENEGRO, L. Narco-Juniors: los herederos del poder criminal (México 2015).

${ }^{135}$ Véase GOODALL, J. y BEKOFF, M. Los diez mandamientos: para compartir el planeta con los animales que amamos (Barcelona 2003).

42 Derecho Animal. Forum of Animal Law Studies, vol. 12/1
} 
- BÁEZ-JORGE, F.Entre los naguales y los santos (Veracruz 2008).

- BARRERA, A. (trad.).El libro de los libros de Chilam Balam (México 2005).

- BASTIDE, R. El prójimo y el extraño. El encuentro de las civilizaciones (Buenos Aires 1973).

- BATTCOCK, C. La conformación de la última "Triple Alianza" en la Cuenca de México: problemas, interrogantes y propuestas. Dimensión Antropológica, 52, (2011) $\mathrm{http} / /$ www.dimensionantropologica.inah.gob.mx/wp-content/uploads/01Dimension52.pdf [Última consulta: 3 de noviembre 2020].

- BEGON, M., HARPER, J.L., TOWNSEND, C.R. Ecología: Individuos, poblaciones y comunidades (Barcelona 1999).

- BENAVENTE, fray Toribio de (Motolinía) Memoriales o libro de las cosas de la Nueva España y de los naturales de ella, Edmundo O’ Gorman (ed.) (México 1971).

- BOURDIEU, P. Cuestiones de Sociología (Madrid 2017).

- BOURDIEU, P. El sentido social del gusto. Elementos para una sociología de la cultura. (México 2017).

- BUENO JIMÉNEZ, A. Los perros en la conquista de América: historia e iconografía. Chronica Nova. Revista De Historia Moderna De La Universidad De Granada, 37 (2017) 177-204. Recuperado de https://www.semanticscholar.org/paper/Los-perros-en-la-conquista-deAmérica\%3A-historia-e-jiménez/c7a54f952839dbd211ea7cc8637d776b1c8c4149 [Última consulta: 30 de sepriembre 2020].

- CABRerA, A. y YEPES, J. Mamíferos Sud-americanos. Historia Natural Ediar, Compañía Argentina de Editores (Buenos Aires 1940).

- CARRASCO, P. "Cultura y sociedad en el México antiguo", Historia general de México (México 2000).

- CARMACK, R. y MONDLOCH, J. Título de Yax y otros documentos quichés de Totonicapán, Guatemala, (México 1989) 33-128.

- CARMACK, R. Y MONDLOCH, J. Título de Totonicapán (México 1989).

- Ceballos, G., LiST, R., Medellín, R., BONACIC, C. y PACHECO, P. Los Felinos de América. Cazadores sorprendentes. (México 2010).

- CEBAllos, G. Los felinos de América (Mexico 2010).

- COLÓN, C. Los Cuatro Viajes del Almirante y su testamento (España 1980).

- RAGSDALE, C., EDGAR, H. \& MELGAR, E. Origins of the Skull Offerings of the Templo Mayor, Tenochtitlán. Current Anthropology, Volume 57 (2016).

- CROSBY, A. El imperialismo ecológico (Barcelona 1988).

- DE BENAVENTE, T. Historia de los Indios de la Nueva España. Real Academia Española. Centro para la Edición de los Clásicos Españoles (Madrid 2014).

- DE LA CRUZ,V. El pensamiento de los binnigula'sa': cosmovisión, religión y calendario con especial referencia a los binnizá (México 2007).

- DE LA GARZA, M. El perro como símbolo religioso entre los mayas y los nahuas. Estudios de cultura Náhuatl, 27, (1997) Recuperado de: http://www.historicas.unam.mx/publicaciones/revistas/nahuatl/pdf/ecn27/519.pdf [Última consulta: 23 septiembre 2020].

- DE LAS CASAS, B. Historia de las Indias. Tomo III. https://www.argentina.gob.ar/sites/default/files/historia_de_las_indias_1_de_las_casas.pdf [Última consulta: 30 septiembre 2020].

- DE LAS CASAS, B. Brevísima relación de la destrucción de las Indias (Madrid 1993).

- DEL RÍO, Octavio. Eva de Naharon. Arqueología Mexicana,157, (México 2017).

- DERRIDA, J. De la Grammatologie (Paris 1967).

- DUSSEL, E. 1492 : el encubrimiento del otro: hacia el origen del mito de la modernidad (1994) Recuperado de http://biblioteca.clacso.edu.ar/clacso/otros/20111218114130/1942.pdf [Última conslta: 20 de octubre 2020].

- DUSSEL, E. Caminos de liberación latinoamericana I. Docencia (Buenos Aires 2015).

- DUSSEL, E. Historia general de la iglesia en América Latina. Tomo I : introducción general a la historia de la iglesia en América Latina (México 1983).

- DUSSEL, E. Para una ética de la liberación latinoamericana. Tomo II (México 1973)

- EliADE, M. Tratado de historia de las religiones. Tomo I http://pdfhumanidades.com/sites/default/files/apuntes/200-Eliade.Mircea_Tratado-de-historia-de- 
las-religiones.pdf [Última consulta: 23 de noviembre 2020].

- EliADE, M. Tratado de historia de las religiones. Tomo II. http://www.fraternidadrosacruzdecolombia.org/wp-content/uploads/2013/12/262_eliade-mirceatratado-de-historia-de-das-religiones-ii.pdf [Última consulta: 24 de noviembre 2020].

- EMBERLEY, J. Venus and Furs: The Cultural Politics of Fur. (Cornelle University Press 1999).

- ENTWISTLE, J. El cuerpo y la moda. Una visión sociológica (Buenos Aires 2002).

- FERNÁNDEZ DE OVIEDO, G. Sumario de la natural historia de las Indias (México 1950).

- FIGUEROA, O., FOSTER, R., WULTSCH, C., MESA-CRUZ, B., KELLY, M., HARMSEN, B., SABIDO, W., MATOLA S. y JACOBSON, S. Estado de Conservación del Jaguar en Belice en El jaguar en el siglo XXI. La perspectiva continental. (México 2016).

- FITZGERALD, S. International wildlife trade: whose business is it? World Wildlife Fund. (Washington, D. C. 1989).

- FOSTER, R. The Ecology of Jaguars (Panthera onca) in a Human-Influenced Landscape, (Southampton 2009).

- FRANÇOIS, C. El dolor redentor. El autosacrificio prehispánico. Universidad Nacional Autónoma de México. (México 2013).

- GALINDO, J. Códice Mendoza. (México 1980).

- GÁMEZ, A. y LÓPEZ, A. Cosmovisión mesoamericana. Reflexiones, polémicas y etnografías (México 2015).

- GIEHL, D. Vegetarianism: A Way of Life (foreword by Isaac Bashevis Singer) (New York 1979).

- GIETELING, C.Jaguar en Ocelot: Biologies, Bedreiging en Bescherming. The Netherlands: Unpublished Report for WWF Germany (Frankfurt 1972)

- GOEBEL, T., WATERS, M. \& O'ROURKE, D. The Late Pleistocene Dispersal of Modern Humans in the Americas. Science 319 (2008) doi: 10.1126/science.1153569. 2008.

- GONZÁlEZ-MAYA, J., BALAGUERA R., ZÁRRATE C. y TRUJILlO, F. Jaguarand Prey Monitoring in South American Llanos, Vichada-Colombia, Jaguar News, 19 (2008). Recuperado de https://silo.tips/download/jose-f-gonzalez-maya-msc [Última consulta: 23 noviembre 2020].

- GONZÁLEZ, Y. Animales y plantas en la cosmovisión mesoamericana. (México 2001).

- GOODALL, J. y BEKOFF, M. Los diez mandamientos: para compartir el planeta con los animales que amamos (Barcelona 2003).

- GRAMSCI, A. Para la reforma moral e intelectual (Madrid 2016).

- GUGGiSBERG, C.A.W. Wild cats of the world. Taplinger (New York 1975).

- GUIRAUD, P. La sémantique (París 1955).

- hoOgesteiJn, R., HOOGESTEIJN, A., TORTATO, F., PAYÁN, E., JEDRZEJEWSKI, W., MARCHINI, S., VALDERRAMA, C. \& BOEDE, E. Consideraciones sobre la peligrosidad del jaguar para los humanos: ¿quién es letal para quién? En II. Conflictos entre felinos y humanos en América Latina (Colombia 2016).

- Rafael Hoogesteijn, Almira L. Hoogesteijn, Fernando Tortato, Esteban Payán, Wlodzimierz

- Jedrzejewski, Silvio M archini, C arlos A . Valderrama-Vásquez y Ernesto O. Boede

- Rafael Hoogesteijn, Almira L. Hoogesteijn, Fernando Tortato, Esteban Payán, Wlodzimierz

- Jedrzejewski, Silvio M archini, C arlos A . Valderrama-Vásquez y Ernesto O. Boede

- HORCASITAS, F. y CRUZ, L. La danza de los tecuanes. Estudios de Cultura Náhuatl,14, (1980) 239-319.

http://www.historicas.unam.mx/publicaciones/revistas/nahuatl/pdf/ecn14/211.pdf

[Última consulta: 01 de noviembre 2020].

- JORGENSON, J. y REDFORD, K. Humans and big cats as predators in the neotropics en Mammals as Predators. (Oxford, 1993).

- KRIPKE, S. Identity and necessity en MUNITZ M. K. (ed.), Identity and Individuation (New York 1971).

- KRUUK, H. Hunter and hunted: Relationships between carnivores and people. (Cambridge, 2002).

- KURTÉN, B. The Pleistocene Jaguar in North America. Bulletin of the Florida State Museum, Biological Series, 9 (1965).

- LEFF, E. Ecología y Capital. Racionalidad ambiental, democracia participativa y desarrollo sustentable (México 1994).

- LEÓN-PORTILLA, HERNÁNDEZ, A. El náhuatl y el tronco lingüístico yutonahua. Arqueología Mexicana, 109 (2011) 32-37. 
- LEÓN-PORTILLA, M. Visión de los vencidos (México 1959).

- LEÓN-PORTILLA, M. Visión de los vencidos. Relaciones indígenas de la conquista (México 1999).

- LEOPOLD, A. Game management (New York 1933).

- LÉVI-STRAUSS, C. Mitologías. Lo crudo y lo cocido (México 1968).

- LEWIS, D. M., y ALPERT, P. Trophy hunting and wildlife conservation in Zambia. Conservation Biology 11 (1997) 59-68 https://doi.org/10.1046/j.1523-1739.1997.94389.x

- LIPOVETSKY, G. El imperio de lo efímero. Moda y su destino en las sociedades modernas (Barcelona 1990).

- LÓPEZ, A. La educación de los antiguos nahuas. VOL. II (México 1985).

- LÓPEZ, A. Las razones del mito. La cosmovisión mesoamericana (México 2015).

- LÓPEZ A. y MILLONES, L. Los Mitos y sus Tiempos. Creencias y narraciones de Mesoamérica y los andes (México 2015).

- LÓPEZ, L. 1993. Las ofrendas del Templo Mayor de Tenochtitlan (México 1993).

- LOTMAN, I. La semiótica de la cultura y el concepto de texto. Recuperado de http://cmas.siu.buap.mx/portal_pprd/work/sites/escritos/resources/LocalContent/40/1/15-20.pdf [Última consulta: 10 noviembre 2020].

- MARCUSE, H. "Industrialization and capitalism in the work of Max Weber", Negations, (New York, 1972).

- MARX, K. El capital: Crítica de la economía política. Tomo I. El proceso de producción del capital. (México 2014).

- MARX, K. El capital. El proceso global de la producción capitalista. Tomo III (México 1977).

- MARX, K. ENGELS, F. La ideología alemana. Crítica de la novísima filosofía alemana en las personas de sus representantes Feuerbach, B. Baauer y Stirner y del socialismo alemán en las de sus diferentes profetas (Barcelona 1974).

- MÁTIR DE ANGLERÍA, P. Décadas del Nuevo Mundo (Buenos Aires 1944).

- MENDOZA, Z. De lo biomédico a lo popular. El proceso salud-enfermedad. Atención en San Juan Copala, Oaxaca (México, 2011).

- MILLER B. y RABINOWITZ A.¿Por qué conservar al jaguar? en El jaguar en el nuevo milenio (México 2002).

- MONTENEGRO, L. Narco-Juniors: los herederos del poder criminal (México 2015).

- MORALES, A., y MORALES, J. Patrimonio cultural y biodiversidad; el caso del jaguar mexicano. Boletín Mexicano de Derecho Comparado, 153 (México 2019) 973-999. https://revistas.juridicas.unam.mx/index.php/derecho-comparado/article/view/13664

- MORALES, A. y MORALES, J. Justicia y vida silvestre: dos estudios de caso sobre ilícitos ambientales del orden federal asociados al jaguar en México en Derecho Animal. Forum of Animal Law Studies. Vol. 9 [Última consulta: 5 de noviembre 2020] (2018). https://doi.org/10.5565/rev/da.335.

- MORSELLI, S. El Título de Totonicapán: consideraciones y comentarios. Estudios Mesoamericanos núm. (México 2004).

- NAVARRETE, F. Prohibición de la danza del Tigre en Tamulté, Tabasco en 1631, Tlalocan, 4 (1971) 374-376. Recuperado de: https://revistasfilologicas.unam.mx/tlalocan/index.php/tl/article/view/271 [Última consulta: 01 de noviembre 2020]-

- NIETZSCHE, F. Aurora. Reflexiones sobre los prejuicios morales (México 2010).

- NORES, A. El dogo argentino (Argentina 1982).

- NOWELL, K. y JACKSON, P. Wild Cats: Status Survey and Conservation Action Plan (Pennsylvania 1996).

- OLIVIER, G. Cacería, sacrificio y poder en Mesoamérica. Tras las huellas de Mixcóatl, "Serpiente de Nube" (México 2015).

- OLIVIER, G. Noches del rey jaguar. Artes de México,121 (México 2016).

- OLIVIER, G. Tepeyóllotl, «Corazón de la montaña y Señor del eco»: el dios jaguar de los antiguos mexicanos, Estudios de Cultura Náhuatl, 28 (1998) 99-140.

- PAYÁN, E y TRUJILLO, L. A.The Tigrilladas in Colombia. Cat News 44 (2006).

- PIÑA, R. y COVARRUBIAS, L. El pueblo del jaguar (los olmecas arqueológicos) (México 1964) $42-48$. 
- RAMÍREZ, J. 2012. El jaguar transformado. Una hipótesis poliédrica a propósito de la danza "El caballito blanco". Estudios de cultura maya, 40 (2012).

- REMI, S. Diccionario de la lengua náhuatl o mexicana, redactado según los documentos impresos y manuscritos más auténticos y precedido de una introducción (México 1977).

- RICARD, R. The Spiritual Conquest of Mexico. An Essay on the Apostolate and the Evangelizing Methods of the Mendicant Orders in New Spain: 1523-1572 (University of California Press 1966).

- RICOEUR, P. Finitud y Culpabilidad (Madrid 2004).

- RIELlO, G. Breve historia de la de la moda. Desde la Edad Media hasta la actualidad. (Barcelona 2016).

- RODAS NÚÑEZ, I. Colonización, cacería y territorio en el Usumacinta Medio, Guatemala en Uso y manejo de Fauna Silvestre en el norte de Mesoamérica (Veracruz, 2010).

- ROSAS-ROSAS, O. y NÚÑ̃Z R. Jaguar y puma, en Ecología y Manejo de Fauna Silvestre en México (México 2014) 349.

- RUÍZ-GARCÍA, M., PAYÁN, E., MURILlO, A. y ÁlVAREZ, D. DNA micro-satellite characterization of the jaguar (Panthera onca) in Colombia. Genes, Genetics and Systematics 81 (2006) 115-127.

- SALT, H. Los derechos de los Animales (Madrid 1999).

- SAUNDERS, N. Tezcatlipoca: jaguar metaphors and the Aztec Mirror of Nature en Signifying Animals: Human Meaning in the Natural World (London 1990).

- SAUSSURE, F. Curso de Lingüística General (Buenos Aires 1945).

- SMITH, B.D. The Initial Domestication of Cucurbita pepo in the Americas 10,000 Years Ago. Science, Vol. 276, (Estados Unidos 1997) Issue 5314, 932-934 DOI: 10.1126/science.276.5314.932 https://science.sciencemag.org/content/276/5314/932 [Última consulta: 12 de noviembre 2020].

- SMITH, N.J.H. Spotted cats and the Amazon skin trade. Oryx 13 (1976) 362-371. Recuperado de DOI: https://doi.org/10.1017/S0030605300014095 [Última consulta: 30 noviembre 2020].

- SNIJDERS, L. Seeing spots: Identification of a codex cover. Mexicon, 36 (2014), 13-14. Recuperado consulta: 6 de noviembre 2020].

- LEOPOLD, A. Fauna Silvestre de México. (California 1959).

- STEINFELD, H., GERBER, P., WASSENAAR, T., CASTEL, V., ROSALES M. y DE HAAN C. La larga sombra del ganado. Problemas ambientales y opciones. Recuperado de http://www.fao.org/3/a-a0701s.pdf [Última consulta: 23 noviembre 2020].

- TELUSHKIN, J. Jewish Wisdom: Ethical, Spiritual, and Historical Lessons from the Great Works and Thinkers. (New York 1994).

- THOUVENOT,M. Diccionario náhuatl-español. Basado en los diccionarios de Alonso de Molina con el náhuatl normalizado y el español modernizado (México 2014).

- URIBE, R. y MAY MAY, B. T'an i K'ajalin Yokot'an Palabra y pensamiento Yokot'an (México 2000).

- VALLE E. Nahuas de la Huasteca. Comisión Nacional para el Desarrollo de los Pueblos Indígenas (México 2005).

- VALVERDE, M. Los lenguajes del símbolo: el jaguar y el poder entre los mayas prehispánicos en Investigaciones de hermenéutica simbólica (México 2001).

- VELA, E. "Narigueras”, Arqueología Mexicana, edición especial núm. 37 (México, 2010).

- VELÁZQUEZ, P. (trad.) Códice Chimalpopoca, Anales de Cuautitlán y Leyenda de los Soles, México, (UNAM 1992).

- WEBB, S. Late Cenozoic Mammal Dispersals Between the Americas, en The Great American Biotic Interchange (Nueva York 1985)-

- WITTGENSTEIN, L. Investigaciones filosóficas (México 1988).

- XIMENEZ, F. Historia Natural del Reino de Guatemala, (Guatemala, 1967).

- YEPES, F. Ganadería y transformación ecosistemas: un análisis ambiental de la política de apropiación territorial en Naturaleza en disputa. Ensayos sobre historia ambiental de Colombia, 1850-1990 (Bogotá 2001).

\section{Documentos}


- Declaración Patrimonio Mundial por la Organización de las Naciones Unidas para la Educación, la Ciencia y la Cultura (UNESCO) en la categoría de paisaje cultural en 2010 Decisión : 34 COM 8B.42. https://whc.unesco.org/es/list/1352.

\section{Fuentes jurídicas}

- SEDUE. Secretaría de Desarrollo Urbano y Ecología. Acuerdo por el que declara veda indefinida del aprovechamiento de la especie jaguar (panthera onca) en todo el territorio nacional, quedando en consecuencia estrictamente prohibida la caza, captura, transporte, posesión y comercio de dicha especie. $\quad$ Abril 23 de 1987.2 Recuperado de http://www.dof.gob.mx/nota_to_imagen_fs.php?codnota $=4651536 \&$ fecha $=23 / 04 / 1987 \&$ cod_diari $\mathrm{o}=200242$ [Última consulta: $\overline{5}$ enero 2021 ] . 